\title{
Kocaeli Üniversitesi
}

Eğitim Dergisi

E-ISSN: 2636-8846

2021 | Cilt 4 | Sayı 1

Sayfa: $137-162$

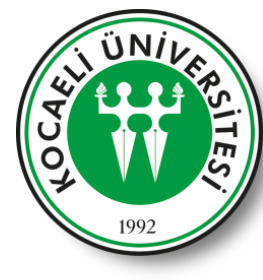

Kocaeli University Journal of Education

E-ISSN: 2636-8846

2021 | Volume 4 | Issue 1

Page: 137-162

Ortaokul öğrencilerinin özetleme başarıları ile özetlemeye yönelik tutumları ve özyeterlik algıları arasındaki ilişki

Exploring relationship between summarizing achievement, and summarizing attitudes and summarizing self-efficacy perceptions of secondary school students

Hatice Kübra Bahçıvan, (D) https://orcid.org/0000-0003-4984-7483 Milli Eğitim Bakanlı̆̆ı, kbrbhcvn50@gmail.com

Gökhan Çetinkaya, (iD https://orcid.org/0000-0001-7676-6852

Pamukkale Üniversitesi, Eğitim Fakültesi, gokhancetinkaya76@hotmail.com

Bu araştırma birinci yazarın "Ortaokul öğrencilerinin özetleme başarıları ile özetlemeye yönelik tutumları ve özyeterlik algıları arasındaki ilișkinin incelenmesi” bașlıklı yüksek lisans tezinden üretilmiștir.

\begin{tabular}{ccc}
\hline & ARAŞTIRMA MAKALESİ & \\
\hline Gönderim Tarihi & Düzeltme Tarihi & Kabul Tarihi \\
31 Mart 2021 & 15 Mayıs 2021 & 27 Mayıs 2021 \\
\hline & &
\end{tabular}




\title{
ÖZ
}

Özetleme, bireyin önemli bilgileri seçerek, önemsiz bilgileri silerek kaynak metni öznel yargılarını katmadan kısa bir biçimde yeniden yapılandırmasıdır. Bu araştırmanın amacı, ortaokul öğrencilerinin özetleme bașarısı ile özetlemeye yönelik tutumları ve özetleme özyeterlik algıları arasındaki ilișkinin incelenmesidir. Çalıșmada genel tarama modellerinden olan ilișkisel tarama modelinden yararlanılmıștır. Çalışma toplam 108 ortaokul öğrencisi ile yürütülmüștür. Katılımcıların özetleme becerileri “Öykü Özeti Değerlendirme Dereceli Puanlama Anahtarı" aracllğılyla öğrencilerin özet metinleri puanlanarak belirlenmiștir. Diğer yandan öğrencilerin özetleme tutumları "Özetlemeye Yönelik Tutum Ölçeği", özetleme özyeterlik algıları ise "Özetleme Özyeterlik Ölçeği" ile belirlenmiștir. Elde edilen veriler istatistik programına aktarılmış ve çözümlemeler yapılmıștır. Elde edilen sonuçlara göre öğrencilerin özetleme başarıları orta ve özyeterlik alglları yeterli düzeydedir. Öğrencilerin özetlemenin önemine inandıkları, özetleme yapmaktan hoşlandıkları ve özetlemeye yönelik yüksek düzeyde olumlu tutumları olduğu görülmüștür. Öğrencilerin özetleme bașarılarının, özetlemeye yönelik tutumlarının ve özetleme özyeterlik algılarının cinsiyet ve sınıf düzeyine göre anlamlı fark göstermediği saptanmıștır. Araștırmanın sonuçları; ortaokul öğrencilerinin özetlemeye yönelik olumlu tutumlarının ve yüksek özyeterlik algılarının özetleme başarısı açısından önemli bir değişken olduğunu ortaya koymuştur. Bunun yanında sınıf düzeyi arttıkça tutumlarının ve özyeterlik algılarının düşmesi dikkat çeken bir sonuçtur. Öğretim ortamlarındaki en büyük yanılgı öğrencilerin özetleme becerilerinin var olduğu düșüncesinden yönelimle okudukları bir romanın ya da ders kitabındaki bir metnin özetlenmesi yönündeki ödevlerin onlara sıklıkla verilmesidir. Öğrencilerin üstesinden gelemeyecekleri özetleme görevleri vermek hem özetlemeye yönelik olumsuz tutuma yol açabilir hem de özetleme özyeterlik algılarını düşürebilir. Bu nedenle öğrencilerin üstesinden gelemeyecekleri özetleme görevlerinden kaçınılması gerekir. Bunun yerine dil gelişimlerine koşut, sıralı ve sarmal bir izlence doğrultusunda aşamalı bir beceri gelişimi benimsenmelidir.

Anahtar Sözcükler: özetleme başarısı, özetleme tutumu, özetleme özyeterlik algısı

\begin{abstract}
Summarizing is a brief reconstruction of the source text by selecting important information, deleting unimportant information, without adding subjective judgments. The aim of this study is to explore the relationship between middle school students' summarizing achievement and their attitudes towards summarizing and their self-efficacy perceptions. Relational screening model, which is one of the general screening models, was used in the study. The study was conducted with a total of 108 secondary school students. Summarizing achievement of the participants was determined by scoring the summaries of the students through the "Story Summary Evaluation Grading Scoring Key". On the other hand, summarizing attitudes of the students were determined with "Attitude Scale towards Summarizing" and their perceptions of summarizing self-efficacy were determined by "Summarizing Self-Efficacy Scale". The data obtained was transferred to the statistical program and analyzes were made. According to the results obtained, the summarizing achievement of the students is medium and their self-efficacy perceptions are sufficient. It was observed that the students believed in the importance of summarizing, they liked to summarize and they had a high level of positive attitude towards summarizing. It was found that students' summarizing achievement, their attitudes towards summarizing, and their perceptions of summarizing self-efficacy did not differ significantly by gender and grade level. Finally, it was determined that there was a moderately significant positive relationship between students' summarizing achievement and their summarizing self-efficacy perceptions and their attitudes towards summarizing. The results of the research; revealed that secondary school students' positive attitudes towards summarizing and their high self-efficacy perceptions are an important variable in terms of their achievement in summarizing. In addition, it is a striking result that as the class level increases, their attitudes and self-efficacy perceptions decrease. The biggest mistake in the teaching environment is that students are often given homework to summarize a novel they read or a text in a textbook, based on the idea that they have summarizing skills. Giving students' summarizing tasks that they cannot cope with may lead to a negative attitude towards summarizing and also reduce their self-efficacy perceptions of summarizing. Therefore, summarizing tasks that students cannot tackle should be avoided. Rather, a gradual skill development should be adopted in line with a sequential and spiral curriculum in line with language developments.
\end{abstract}

Keywords: summarizing achievement, summarizing attitude, summarizing self-efficacy perception

Hatice Kübra Bahçıvan, Gökhan Çetinkaya

Ortaokul öğrencilerinin özetleme başarıları ile özetlemeye yönelik tutumları ve özyeterlik algıları arasındaki ilişki 


\section{GíRiș}

Özetleme edimi anlama ve anlatma alt becerilerini de gerektiren çok boyutlu üst bilişsel bir stratejidir. Bu yüzden özet metin yazma süreci anlama ve anlatma becerilerini kapsayan çok boyutlu bilişsel işlemlemeyi gerekli kılar. Bireyin kaynak metni özetleme amaçlı okuma sürecinde kavrama çabasının yanında özet metni yapılandıracağı öğelere de odaklanması ve özetleme sürecinin aşamalarına ilişkin stratejileri işe koşması gerekir. Öte yandan, "yeni bir metin oluşturma yeni içeriklerin tasarlanması ve oluşturulması sürecini içerirken özet metin oluşturma kaynak metnin birleștirilmesini ve yorumlanmasını gerektirir" (Hidi \& Anderson, 1986).

Özetleme, kaynak metni okuyan ya da dinleyen bireyin seçme, birleştirme, yorumlama, genelleme ve keşfetme gibi üst bilişsel stratejileri işleterek daha kısa bir metin oluşturma sürecidir. Diğer bir deyişle özetleme, kaynak metnin okunarak önemli bölümlerinin seçilmesi, metnin büyük ölçekli yapısıyla tutarlı olarak anlamsal bütünlüğün yeniden oluşturulması sürecini kapsayan bir edimdir (Çetinkaya, Şentürk, \& Dikici, 2020).

İlgili çalışmaların sonuçları öğrencilerin özetleme amaçlı okuma ve özet metin oluşturma becerilerinin zayıf olduğu yönündedir (Susar Kırmızı, \& Akkaya, 2011; Eyüp, Stebler, \& Yurt, 2012; Karatay \& Okur, 2012; Karatay, Güngör, Bolat, \& Okur, 2013; Bahap Kudret ve Baydık, 2016). Bununla birlikte öğrencilerin özet metin oluşturmanın anlama ve anlatma sürecinde işletilmesi gereken stratejileri de yetkinlikle kullanamadıkları görülmektedir (Delaney, 2008; Susar \& Akkaya, 2009; Chiang, Therriault, \& Frank, 2010; Sulak \& Arslan, 2017).

"Brown ve Day (1983) öğrencilerin özetleme becerilerinin sıralı olarak geliștiğini belirtir." (Akt. Çetinkaya \& Polat Demir 2017:207). Bu bağlamda özetleme becerisini geliştirmeye dönük uygun stratejiler konusunda öğrencilerin bilgilendirilmesi, uygulama yapılması ve sonucunda özet metne geribildirim sunulması gerekir (Çetinkaya \& Polat Demir 2017:208). Tüm bunlar öğrencilerin özetlemeye yönelik olumlu ya da olumsuz tutum geliștirmesinde belirleyici olabilir.

Tutum, bilişsel, duyuşsal ve davranışsal olmak üzere üç bileşen içeren belli bir öğrenme ortamında zaman içinde geliştirilen bir dizi kanıdır (Wenden 1991). Bu çalışma çerçevesinde özetlemeye yönelik tutum, bireyin özetleme yapmaktan hoşlanması ve özetlemenin önemine inanması olmak üzere iki boyuttan oluşan bir ruhsal yönelim olarak ele alınmıştır.

Öğrenmeye yönelik tutumun davranışları ve başarıyı etkilediği kabul edilir. Çalışmaların sonuçları okuma ve yazmaya yönelik tutum ile başarı arasında anlamlı bir ilişki olduğu yönündedir (Clark, 2012; Bulut, 2017). Tutumun öğrencilerin okuma ve yazma başarısı üzerindeki etkisinin temel nedeni öğrencilerin bilişsel katılımını etkilemesidir (McKenna, Kear, \& Ellsworth, 1995). Çünkü tutum bireyin öğrenme güdüsünü ve verilen göreve yaklaşımını yönlendirir. Alexander ve Filler (1976) okuma tutumlarını "Öğrencinin bir okuma durumuna yaklaşmasını ya da durumdan kaçınmasını yönlendiren bir duygu dizgesi" olarak tanımlar. Tutum, katılım ve uygulama gibi etmenleri yönlendirerek öğrencinin başarı erişi düzeyini etkileyebilir.

Öğrenme sürecini yönlendiren ve akademik başarı üzerinde etkisi olan bir diğer duyuşsal değişken de özyeterliktir. Özyeterlik, bireyin olası durumların üstesinden gelmek için gereken eylem yollarını ne kadar iyi yürütebileceğine ilişkin kanısı olarak tanımlanabilir (Bandura, 1982:122). Çoğu eylem akışı ilk olarak düşüncede biçimlenir. Bireyin yeterliğine yönelik algısı yapılandırma ve öğrenme durumuna yön veren bir etkendir. Özyeterlik duygusu yüksek olanların aklında başarımını besleyen ve olumlu yönlendiren başarı tasarımları vardır. Yeterliğinden kuşku duyan bireyin ise aklında birçok şeyin yolunda gitmeyeceği ve başarısız olacağı tasarımı vardır. Kendinden kuşku ile savaşırken bireyin başarı kazanması zordur. (Bandura, 1993).

Yüksek özyeterlik düzeyleri yüksek hedef belirleme, öğrenme stratejilerini daha fazla kullanma ve kaygının düşük olması gibi birçok olumlu çıktı sağlar (Bong, 2006). Özyeterlik, özellikle beceri odaklı görev zor ve düşük güdüleyici özelliğe sahip olduğunda çok önemlidir. Araştırmaların 
sonuçları genel olarak özyeterliğin öğrencinin akademik başarısını belirleyen başat bir duyuşsal değişken olduğu yönündedir (Fenning \& May, 2013; Boakye, 2015; Honicke \& Broadbent, 2016; Zumbrunn, Broda, Varier, \& Conklin, 2019).

Temel dil becerilerinden okuma ve yazma ile ilgili çalışmaların sonuçları da genel olarak özyeterlik ile okuma ve yazma başarısı arasında olumlu yönde ilişki olduğuna işaret etmektedir (Demir, 2013; İnnalı \& Aydın, 2014; Altunkaya, 2018; Yamaç \& Öztürk, 2018; Ülper \& Şirin, 2019).

Yukarıda anılan araştırma sonuçları özyeterlik ile ilgili beceri alanları başarısı arasındaki ilişkiyi açıkça ortaya koymaktadır. Yazma özyeterliği, kişinin yazma görevlerini başarılı bir biçimde planlama ve yürütme becerilerine ilişkin algıları olarak tanımlanır (Zimmerman \& Bandura, 1994). Okuma özyeterliği de akıcı okuma ve kavrama gibi görevleri başarılı bir biçimde yerine getirme becerilerine ilişkin algıdır (Peura vd., 2019). Bu çalışmanın çerçevesi doğrultusunda özetleme özyeterliği bireyin özetleme amaçlı okuma ve özet metin yazma gibi görevleri başarılı bir biçimde yerine getirme becerilerine ilişkin algı olarak tanımlanabilir.

\section{Araştırmanın Amacı}

Araştırmanın temel amacı, ortaokul öğrencilerinin özetleme başarıları ile özetlemeye yönelik tutumları ve özyeterlik algılarına ilişkin görünümlerin ve bunlar arasındaki ilişkinin incelenmesidir. Araștırmanın temel amacı doğrultusunda şu sorulara yanıt aranmıştır:

1. Öğrencilerin özetleme başarıları nasıldır?

2. Öğrencilerin özetleme başarıları sınıf düzeyine göre farklılık göstermekte midir?

3. Öğrencilerin özetleme başarıları cinsiyete göre farklılık göstermekte midir?

4. Öğrencilerin özetlemeye yönelik tutumları nasıldır?

5. Öğrencilerin özetlemeye yönelik tutumları sınıf düzeyine göre farklılık göstermekte midir?

6. Öğrencilerin özetlemeye yönelik tutumları cinsiyete göre farklılık göstermekte midir?

7. Öğrencilerin özetlemeye yönelik özyeterlik algıları nasıldır?

8. Öğrencilerin özetlemeye yönelik özyeterlik algıları sınıf düzeyine göre farklılık göstermekte midir?

9. Öğrencilerin özetlemeye yönelik özyeterlik algıları cinsiyete göre farklılık göstermekte midir?

10.Öğrencilerin özetleme başarıları ile özetlemeye yönelik tutum ve özetlemeye yönelik özyeterlik algı puanları arasında anlamlı bir ilişki var mıdır?

\section{Araştırmanın Önemi}

Özetleme okuduğunu anlama becerisinin geliştirilmesi ve öğrenilen bilgilerin uzun süreli bellekte kalıcı kılınması için işe koşulan üstbilişsel bir öğrenme stratejisidir. Özet metin oluşturma sınıf içi ortamlarda öğretmenler tarafından sıklıkla öğrencilere görev olarak verilir. Fakat bu görev genel olarak okunan bir öykünün ya da bilgilendirici bir metnin ya da okunan bir romanın özet metninin çıkarılması yönündedir. Öğretmenler tarafından öğrencilere verilen bu görevin öğrencilerin özetleme edimine yönelik tutumlarını olumsuz etkileyebileceği söylenebilir. Çünkü ilgili çalışmaların sonuçları her sınıf düzeyinde öğrencilerin özet metin yazma becerilerinin zayıf olduğu yönünde bir görünüm sunar (Çıkrıkçı, 2004; Susar Kırmızı \& Akkaya,2011; Karatay, Güngör, Bolat, \& Okur, 2013).

Özetleme becerilerinin öğrencilere dizgeli ve tasarlanarak kazandırılması gerekir. Öğrencilerin bu beceriyi kazanabilmesi için özetleme amaçlı okuma ve taslak özet metin oluşturma sürecinde işe koşabileceği stratejileri öğrenmesi ve bu stratejileri uygulayabilme konusunda beceri geliştirmesi ön koşuldur (Çetinkaya, Şentürk, \& Dikici, 2020). Öğrencilerin özetleme stratejilerini kullanma düzeyine ilişkin çalışmaların sonuçlarından yönelimle özetleme stratejilerini kullanma konusunda da tüm sınıf düzeyinden öğrencilerin yetersiz bir görünüm sergiledikleri söylenebilir (Deneme, 2009; Susar Kırmızı \& Akkaya, 2011; Eyüp, Stebler, \& Uzuner Yurt, 2012). 
Alanyazındaki çalışmalar öğrencilerin okuma ve yazmaya yönelik tutumları ya da okuma ve yazma özyeterliği ile bu alandaki başarımları arasındaki ilişki üzerinde yoğunlaşmaktadır. Özetleme başarısı ile özetlemeye yönelik tutum ve özyeterlik algıları arasındaki ilişkiyi ele alan çalışmanın olmaması önemli bir eksiklik olarak dikkat çekmektedir. Bu çalışmanın önemi özetleme başarısı ile özetlemeye yönelik tutum ve özyeterlik algısı arasındaki ilişkiye dönük görünümü sunan ilk çalışma olması ve konuyla ilgili yapılacak çalışmalara sağlayacağı olası katkı açısından belirginleşmektedir

\section{YÖNTEM}

\section{Katılımcı Bilgisi}

Amacı, ortaokul öğrencilerinin özetleme başarıları ile özetlemeye yönelik tutum ve özetleme özyeterlik algıları arasındaki ilişkinin incelenmesi olan bu çalışmanın katılımcılarını 2019-2020 eğitim-öğretim yılında Gaziantep ilinin Nizip ilçesinde bir devlet okulunda öğrenimini sürdüren 108 ortaokul öğrencisi oluşturmuştur. Katılımcılar tabakalı örnekleme yöntemine göre basit seçkisiz bir yolla belirlenmiştir.

Katılımcların \%16,7'si (N=18) 5. sinıfta, \%27,8'i (N=30) 6. sinıfta, \%27,8'i (N=30) 7. sinıfta ve $\% 27,8^{\prime} i(N=30)$ 8. sınıfta öğrenim görmektedir. Öğrencilerin \%51,9’u kız, \%48,1'i erkektir.

\section{Veri Toplama Araçları}

Araştırmada veri toplama aracı olarak "Özetleme Özyeterlik Algısı Ölçeği”, "Özetlemeye Yönelik Tutum Ölçeği” ve “Öykü Özeti Değerlendirme Dereceli Puanlama Anahtarı” kullanılmıştır.

\section{Özetleme özyeterlik algısı ölçeği}

Özetleme Özyeterlik Algısı Ölçeği, öğrencilerin özetleme konusunda kendilerini yeterli hissetme düzeyini belirlemek amacıyla Çetinkaya ve Bayat (yayım sürecinde) tarafından geliştirilmiştir. Ölçeğin geçerlik çalışması kapsamında yapı geçerliği incelenmiş ve açımlayıcı faktör analiziyle doğrulayıcı faktör analizi yapılmıştır. Açımlayıcı faktör analizi sonucunda 14 maddeden ve iki alt boyuttan oluşan bir ölçek elde edilmiştir. Ölçeğin ilk boyutu "Özet Yazma" ikinci boyutu "Özetleme Amaçlı Okuma" olarak adlandırılmıștır. Özet Yazma alt boyutunda beș, Özetleme Amaçlı Okuma boyutunda ise dokuz madde yer almaktadır. Ölçekteki maddelerin her birinde kendilerini yeterli hissetme düzeyleri "1: Hiçbir zaman, 2: Nadiren, 3: Kararsızım, 4: Genellikle, 5: Her zaman" biçiminde derecelendirilmiştir. Ölçeğin güvenilirliğini belirlemek amacıyla iç tutarlılık katsayısı hesaplanmıştır. Özet Yazma alt boyutu için Cronbach alfa güvenirlik katsayısı 0.832, Özetleme Amaçlı Okuma alt boyutu için Cronbach alfa güvenirlik katsayısı 0.756 bulunmuştur. Ölçeğin tamamı için ise Cronbach alfa güvenirlik katsayısı 0.860 bulunmuştur.

\section{Özetlemeye yönelik tutum ölçeği}

Özetlemeye Yönelik Tutum Ölçeği Çetinkaya ve Polat-Demir (2016) tarafından geliştirilmiştir. Ölçeğin geçerlik çalıșması kapsamında yapı geçerliği incelenmiș ve ölçeğin yapı geçerliğine ilişkin kanıtlar ortaya koymak amacıyla açımlayıcı faktör analizi ve doğrulayıcı faktör analizi birlikte kullanılmıştır. Açımlayıcı faktör analizi sonucunda 27 madde ve iki alt boyuttan oluşan bir tutum ölçeği elde edilmiştir. Tutum ölçeğinde yer alan maddelerin 16'sı olumlu 11'i olumsuz maddelerdir. Ölçekteki tutum ifadesinin her biri katılıp katılmama durumuna göre ' 5 ' Tamamen Katılıyorum, '4' Katılıyorum, '3' Kısmen Katılıyorum, '2' Katılmıyorum ve '1' Hiç Katılmıyorum biçiminde derecelendirilmiştir. Birinci boyutta yer alan maddeler özetleme yapmaktan hoşlanmayı ve hoşlanmamayı ifade ettiği için bu boyut "Özetleme Yapmaktan Hoşlanma" olarak adlandırılmıştır. İkinci boyutta yer alan maddeler de özetlemenin önemine yönelik tutum ifadeleri olduğu için bu boyut da "Özetlemenin Önemine İnanma" olarak adlandırılmıştır. Özetleme Yapmaktan Hoşlanma alt boyutundaki maddelerin dokuzu olumlu, altısı olumsuz tutum ifadeleriyken, Özetlemenin Önemine İnanma alt boyutundaki maddelerin yedisi olumlu, beşi olumsuz tutum ifadeleridir. Doğrulayıcı faktör analizi sonucunda Özetlemeye Yönelik 
Tutum Ölçeği'nin faktör yapısının başka bir çalışma grubundan elde edilen verilerde doğrulandığı belirlenmiştir. Ölçeğin güvenirlik çalışması kapsamında Cronbach alfa güvenirlik katsayısı hesaplanmıştır. Yapılan güvenirlik analizi sonucunda Özetleme Yapmaktan Hoşlanma boyutuna ilişkin iç tutarlılık güvenirlik katsayısı 0.901, Özetlemenin Önemine İnanma boyutuna ilişkin iç tutarlılık güvenirlik katsayısı 0.903 bulunmuştur. Ölçeğin tamamına ilişkin güvenirlik katsayısı ise 0.931 bulunmuştur.

\section{Öykü özeti değerlendirme dereceli puanlama anahtarı}

Öykü Özeti Değerlendirme Dereceli Puanlama Anahtarı, ortaokul öğrencilerinin düzeyine uygun olarak belirlenen Sinagrit Baba (Abasıyanık, 2016) öyküsünü özetlemeleri istenen öğrencilerin özet metinlerini puanlamak amacıyla araștırmada kullanılmıştır. İlk olarak öğrencilerden bu öyküyü özetleme amaçlı okuması istenmiştir. Sonrasında da öykünün özetini yazmaları belirtilmiştir. Öğrencilerin oluşturdukları özet metinleri "Öykü Özeti Değerlendirme Dereceli Puanlama Anahtarı" ölçütlerine göre puanlanmıştır.

Öykü Özeti Değerlendirme Dereceli Puanlama Anahtarının hazırlanmasında, Goodrich'in (2001) önerdiği basamaklardan yararlanılmıştır. Bu basamaklar şöyledir:

a) Başarımı belirlemede kullanılacak ölçütlerin listelenmesi: Özet başarımını belirlemek için öykü metninin yapısı doğrultusunda "Giriș", "Temel Olaylar", "Sonuç" ve her metin türünün özetinde bulunması gereken "Düzen ve Yazım Niteliği" başlıkları olmak üzere dört ulam belirlenmiștir. "Giriş̧" ulamında özetin tüm ana karakterlerin ve kurgunun açıklamasını tam olarak içerip içermediği, öyküdeki temel çatışmanın ayrıntılı bir biçimde anlatılıp anlatılmadığı ölçüt alınmıştır. "Temel olaylar" ulamında öykünün başındaki, ortasındaki ve sonundaki önemli olayların özenle seçilip seçilmediği ve tam olarak anlatılma durumu ölçüt alınmıştır. "Sonuç" ulamında doruk noktasının, çatışma çözümünün ve izleğin ayrıntılı açıklanıp açıklanmadığı temel alınmıştır. Son olarak "Düzen ve Yazım Niteliği" ulamında özet metnin ne derece özenle yazıldığı ve ne kadar yeniden düzenleme gerektirdiği ölçüt alınmıştır.

b) Kullanılacak dereceli puanlama anahtarına karar verilmesi: Beceri alanına ilișkin görevin puanlanmasına uygun olmasından ve öğrencilerin yazdıkları özetlerin ayrıntılı bir biçimde puanlanması istendiğinden dolayı araştırmada "çözümlemeli dereceli puanlama anahtarı" kullanılmıştır.

c) Başarım düzeylerinin belirlenmesi ve düzey tanımlamalarının yapılması: Öğrenciler tarafından yazılan özetin belirlenen ölçütleri ne kadar yerine getirip getirmediğini ortaya koymak için beș başarı düzeyi belirlenmiş ve düzey tanımlamaları her bir ölçüt için ayrı ayrı tanımlanmıştır. Buna göre ölçütte istenilen başarımı tam olarak yerine getiren özetler " 5 ", hiç başarım ortaya koyamayan özetler "0" olarak puanlanmıştır.

d) Uzman görüşlerinin alınması: Son aşamada ise, dereceli puanlama anahtarının geçerliğini sağlamak için ölçme ve değerlendirme ile dil alanı olmak üzere iki uzmandan görüş alınmış ve dereceli puanlama anahtarı hazır duruma getirilmiştir.

\section{Verilerin Toplanması}

Uygulamadan önce veri toplama araçları ve uygulama süreci hakkında bilgilendirilen katılımcılardan ilk olarak Sinagrit Baba (Abasıyanık, 2016) öyküsünü özetleme amaçlı okumaları ve sonrasında öykünün özetini yazmaları istenmiștir. Öğrencilerin oluşturdukları özet metinler "Öykü Özeti Değerlendirme Dereceli Puanlama Anahtarı" ölçütlerine göre iki farklı uzman tarafından puanlanmıştır. Öğrencilerin yazdıkları özet metinleri puanlayan iki araştırmacının puanları arasında 0.92 korelasyon bulunmuştur. İki puanlayıcının puanlarının aritmetik ortalaması rubrikten elde edilen puan olarak alınmış ve araștırmanın verileri olarak istatistiksel analize tabi tutulmuştur. Öğrenciler özet metni oluşturduktan sonra "Özetleme Özyeterlik Algısı Ölçeği" ve "Özetlemeye Yönelik Tutum Ölçeği” dağıtılarak öğrencilerden maddelerin yanıtlanması istenmiştir. 


\section{Verilerin Analizi}

Veriler, SPSS 22.0 istatistik paket programları kullanılarak çözümlenmiştir. Verilerin analizinde anlamlılık düzeyi (p) 0.05 kabul edilmiştir. Verilerin analizinde kullanılan yöntemler araştırma soruları için aşağıda sırasıyla verilmiştir.

Ortaokul öğrencilerinin özetleme başarıları, özetlemeye yönelik tutum ve özetlemeye yönelik özyeterlik algı düzeylerini belirlemek amacıyla betimsel istatistiklerden yararlanılmıştır. Öğrencilerin Öykü Özeti Değerlendirme Dereceli Puanlama Anahtarından aldıkları ortalama puanların hangi başarı düzeyine denk geldiğini belirlemek amacıyla puan aralıkları belirlenmiştir. Bu aralıklara göre öğrencilerin hem puanlama anahtarının tamamından hem de her bir ölçütten elde ettikleri puanların karşllık geldiği başarı düzeyi belirlenmiştir. Benzer biçimde Özetleme Özyeterlik Ölçeği'nden ve Özetlemeye Yönelik Tutum Ölçeği'nden elde edilen ortalama puanları için katılım düzeylerine karşılık gelen puan aralıkları belirlenmiştir. Bu ölçeklerde de maddelerden, alt boyutlardan ve ölçeklerin tamamından elde edilen puanlara karşılık gelen düzeyler belirlenmiştir.

Puanlama anahtarındaki başarı düzeylerine ve ölçeklerdeki yanıtlama seçeneklerine karşılık gelen puan aralıkları Tablo (1)'de gösterilmiştir.

\section{Tablo 1}

Puanlama Ulamlarına Karşıllı Gelen Puan Aralıkları

\begin{tabular}{cccccc}
\hline \multicolumn{2}{c}{$\begin{array}{c}\text { Öykü Özeti Değerlendirme } \\
\text { Dereceli Puanlama Anahtarı }\end{array}$} & \multicolumn{2}{c}{ Özetleme Özyeterlik Ölçeği } & \multicolumn{2}{c}{ Özetlemeye Yönelik Tutum Ölçeği } \\
\hline Puan Aralığı & Başarı Düzeyi & Puan Aralığı & Düzey & Puan Aralı̆̆ & Düzey \\
\hline $0 \leq \bar{X}<0.80$ & Çok zayıf & $1 \leq \bar{X}<1.80$ & Hiçbir zaman & $1 \leq \bar{X}<1.80$ & Hiç katılmıyorum \\
$0.80 \leq \bar{X}<1.60$ & Zayıf & $1.80 \leq \bar{X}<2.60$ & Nadiren & $1.80 \leq \bar{X}<2.60$ & Katılmıyorum \\
$1.60 \leq \bar{X}<2.40$ & Orta & $2.60 \leq \bar{X}<3.40$ & Kararsızım & $2.60 \leq \bar{X}<3.40$ & Biraz Katılıyorum \\
$2.40 \leq \bar{X}<3.20$ & İyi & $3.40 \leq \bar{X}<4.20$ & Genellikle & $3.40 \leq \bar{X}<4.20$ & Katılıyorum \\
$3.20 \leq \bar{X} \leq 4.00$ & Çok iyi & $4.20 \leq \bar{X} \leq 5.00$ & Her zaman & $4.20 \leq \bar{X} \leq 5.00$ & Tamamen \\
\hline
\end{tabular}

Ortaokul öğrencilerinin cinsiyetlerine göre özetleme başarıları, özetlemeye yönelik tutumları ve özetleme özyeterlik algıları arasında anlamlı bir fark olup olmadığını belirlemek için öncelikle normallik varsayımının karşılanıp karşılanmadığı sınanmıștır. Bu amaçla her bir ölçme aracından elde edilen puanlara ilişkin çarpıklık ve basıklık katsayıları hesaplanmış ve bu değerlerin -1 ile +1 sinırları içerisinde kaldığı belirlenmiştir. Bu bulgulara puanların normal dağılımdan önemli bir sapma göstermediği sonucuna ulaşılmıştır. Puanların normal dağılım göstermesinden dolayı puanlar arasındaki farkın cinsiyete göre anlamlı olup olmadığı parametrik yöntemlerden Bağımsız Örneklemler t-testiyle sınanmıştır.

Ortaokul öğrencilerinin sınıf düzeylerine göre özetleme başarıları, özetlemeye yönelik tutumları ve özetleme özyeterlik algıları arasında anlamlı bir fark olup olmadığı ise beşinci sınıftaki öğrenci sayısı 30'un altında olduğu için parametrik olmayan yöntemlerden Kruskal Wallis testi ile sınanmıştır. Kruskal Wallis Testi, az sayıda denekten oluşan tek faktörlü gruplar arası çalışmalarda grupların bir değişkene ait puanları arasında anlamlı fark olup olmadığını test etmek amacıyla kullanılır (Büyüköztürk, 2012).

"Ortaokul öğrencilerinin özetleme başarıları ile özetlemeye yönelik tutumları ve özetleme özyeterlik algıları arasında anlamlı bir ilişki var mıdır?" sorusuna yanıt bulabilmek için Pearson Momentler Çarpımı korelasyon katsayısından yararlanılmıştır.

\section{Araştırma Etiği}

$\mathrm{Bu}$ araştırmanın planlanmasından, uygulanmasına, verilerin toplanmasından verilerin analizine kadar olan tüm süreçte "Yükseköğretim Kurumları Bilimsel Araştırma ve Yayın Etiği Yönergesi" kapsamında uyulması belirtilen tüm kurallara uyulmuştur. Yönergenin ikinci bölümü olan Hatice Kübra Bahçıvan, Gökhan Çetinkaya Ortaokul öğrencilerinin özetleme başarıları ile özetlemeye yönelik tutumları ve özyeterlik algıları arasındaki ilişki 
“Bilimsel Araştırma ve Yayın Etiğine Aykırı Eylemler” başlı̆̆ı altında belirtilen eylemlerden hiçbiri gerçekleştirilmemiştir.

$\mathrm{Bu}$ çalışmanın yazım sürecinde bilimsel, etik ve alıntı kurallarına uyulmuş; toplanan veriler üzerinde herhangi bir tahrifat yapılmamış ve bu çalışma herhangi başka bir akademik yayın ortamına değerlendirme için gönderilmemiştir.

\section{Etik kurul izin bilgileri}

Etik değerlendirmeyi yapan kurul adı: Niğde Ömer Halisdemir Üniversitesi

Etik değerlendirme kararının tarihi: 01.07.2020

Etik değerlendirme belgesi sayı numarası: 2020/06-02

\section{BULGULAR}

\section{Öğrencilerin Özetleme Başarısı}

Araştırmanın birinci sorusu “Öğrencilerin özetleme başarıları nasıldır?” biçiminde oluşturulmuştur. Bu soruya yanıt aramak için öğrencilerin "Öykü Özeti Değerlendirme Dereceli Puanlama Anahtarı" ölçütlerine ilișkin puanların ortalaması ve özet metnin tamamına ilișkin puan ortalaması belirlenmiștir. Elde edilen bulgular Tablo 2'de gösterilmektedir:

Tablo 2

Öykü Özeti Değerlendirme Dereceli Puanlama Anahtarından Elde Edilen Puanlara İlişkin Betimsel Istatistikler

\begin{tabular}{lccc}
\hline Ölçütler & $\bar{X}$ & Düzey & Sx \\
\hline Giriş & 1.87 & Orta & 1.03 \\
Temel olaylar & 1.87 & Orta & 1.15 \\
Sonuç & 1.71 & Orta & 1.31 \\
Düzen & 2.17 & Orta & 1.04 \\
Toplam & 1.91 & Orta & 1.02 \\
\hline
\end{tabular}

Tablo 2 incelendiğinde öğrencilerin Öykü Özeti Değerlendirme Dereceli Puanlama Anahtarı ulamlarından Giriş ölçütüne ilişkin puanlarının ortalaması $\bar{X}=1.87$, Temel Olaylar ölçütüne ilișkin puanlarının ortalaması $\bar{X}=1.87$, Sonuç ölçütüne ilişkin puanlarının ortalaması $\bar{X}=1.71$ ve Düzen ölçütüne ilişkin puanlarının ortalaması $\bar{X}=2.17$ 'dir. Bu puanlara göre öğrencilerin özeti kurallara uygun olarak yazmasını gerektiren Düzen bölümünde en yüksek başarı gösterdiği, en az başarıyı ise Sonuç bölümünü yazarken gösterdiği belirlenmiştir. Öğrencilerin özet metinlerinin tamamına ilişkin puanlarının ortalaması $\bar{X}=1.91$ 'dir. Öğrenciler hem ölçütlerin tamamında hem de özetin tamamında "orta" düzeyde başarım ortaya koymuştur.

\section{Sınıf Düzeylerine Göre Öğrencilerin Özetleme Başarısı}

Araștırmanın ikinci sorusu "Öğrencilerin özetleme başarıları sınıf düzeyine göre farklılık göstermekte midir?" biçiminde oluşturulmuştur. Bu soruya yanıt aramak için öğrencilerin "Öykü Özeti Değerlendirme Dereceli Puanlama Anahtarı" ölçütlerine ilişkin puanların ortalaması ve özet metnin tamamına ilişkin puan ortalaması her sınıf düzeyinde belirlenmiştir. Elde edilen bulgular Tablo 3'te gösterilmektedir:

Tablo 3 incelendiğinde 5. sınıftaki öğrencilerin Öykü Özeti Değerlendirme Dereceli Puanlama Anahtarından aldıkları puanların ortalaması $\bar{X}=2.07$, 6. sınıftaki öğrencilerin puanlarının ortalaması $\bar{X}=1.96,7$. sinıftaki öğrencilerin puanlarının ortalaması $\bar{X}=1.78$ ve 8 . sinıftaki öğrencilerin puanlarının ortalaması $\bar{X}=1.88$ 'dir. Ortalama puanlar incelendiğinde farklı sınıf düzeylerindeki öğrencilerin "orta" düzeyde performans ortaya koydukları görülmektedir. 
Kruskal Wallis testi sonuçları incelendiğinde öğrencilerin öykü özetleme puanları arasında sınıf düzeyine göre anlamlı düzeyde fark olmadığı belirlenmiștir $(\chi 2=.608, \mathrm{p}>0.05)$.

\section{Tablo 3}

Sınıf Düzeyi Değişkenine Göre Özetleme Puanı Kruskal Wallis Testi Sonuçları

\begin{tabular}{|c|c|c|c|c|c|c|c|c|c|}
\hline Beceri & Sınıf Düzeyi & $\mathrm{N}$ & $\bar{X}$ & $\begin{array}{l}\text { Başarı } \\
\text { Düzeyi }\end{array}$ & Sx & $\begin{array}{c}\text { Sira } \\
\text { Ortalaması }\end{array}$ & $\mathrm{Sd}$ & $x^{2}$ & $\mathrm{P}$ \\
\hline \multirow{4}{*}{ Giriş } & 5 & 18 & 1.83 & Orta & 0.79 & 54.69 & \multirow{4}{*}{3} & \multirow{4}{*}{1.782} & \multirow{4}{*}{$.61 \mathrm{c}$} \\
\hline & 6 & 30 & 2.07 & Orta & 0.98 & 60.33 & & & \\
\hline & 7 & 30 & 1.77 & Orta & 0.97 & 52.30 & & & \\
\hline & 8 & 30 & 1.80 & Orta & 1.27 & 50.75 & & & \\
\hline \multirow{4}{*}{$\begin{array}{l}\text { Temel } \\
\text { Olaylar }\end{array}$} & 5 & 18 & 2.17 & Orta & 0.92 & 63.11 & \multirow{4}{*}{3} & \multirow{4}{*}{2.523} & \multirow{4}{*}{.471} \\
\hline & 6 & 30 & 1.97 & Orta & 1.25 & 56.53 & & & \\
\hline & 7 & 30 & 1.67 & Orta & 1.06 & 49.77 & & & \\
\hline & 8 & 30 & 1.80 & Orta & 1.27 & 52.03 & & & \\
\hline \multirow{4}{*}{ Sonuç } & 5 & 18 & 1.83 & Orta & 1.54 & 56.00 & \multirow{4}{*}{3} & \multirow{4}{*}{.899} & \multirow{4}{*}{.826} \\
\hline & 6 & 30 & 1.67 & Orta & 1.49 & 52.53 & & & \\
\hline & 7 & 30 & 1.57 & Zayıf & 1.19 & 51.73 & & & \\
\hline & 8 & 30 & 1.83 & Orta & 1.12 & 58.33 & & & \\
\hline \multirow{4}{*}{ Düzen } & 5 & 18 & 2.44 & İyi & 1.34 & 60.00 & \multirow{4}{*}{3} & \multirow{4}{*}{.921} & \multirow{4}{*}{.820} \\
\hline & 6 & 30 & 2.13 & Orta & 1.01 & 53.80 & & & \\
\hline & 7 & 30 & 2.13 & Orta & 0.86 & 54.87 & & & \\
\hline & 8 & 30 & 2.07 & Orta & 1.05 & 51.53 & & & \\
\hline \multirow{4}{*}{ Özet } & 5 & 18 & 2.07 & Orta & 1.05 & 59.08 & \multirow{4}{*}{3} & \multirow{4}{*}{.608} & \multirow{4}{*}{895} \\
\hline & 6 & 30 & 1.96 & Orta & 1.10 & 55.27 & & & \\
\hline & 7 & 30 & 1.78 & Orta & 0.90 & 52.35 & & & \\
\hline & 8 & 30 & 1.88 & Orta & 1.08 & 53.13 & & & \\
\hline
\end{tabular}

5. sınıftaki öğrencilerin Giriş ölçütünden aldıkları puanların ortalaması $\bar{X}=1.83$, 6. sınıftaki öğrencilerin puanlarının ortalaması $\bar{X}=2.07$, 7. sınıftaki öğrencilerin puanlarının ortalaması $\bar{X}$ $=1.77$ ve 8. sınıftaki öğrencilerin puanlarının ortalaması $\bar{X}=1.80$ 'dir. Ortalama puanlar incelendiğinde farklı sınıf düzeylerindeki öğrencilerin özetin giriș ulamında "orta" düzeyde başarım ortaya koyduğu görülmektedir. Kruskal Wallis testi sonuçları incelendiğinde öğrencilerin giriş puanları arasında sınıf düzeyine göre anlamlı düzeyde fark olmadığı belirlenmiştir $(\chi 2=1.782, \mathrm{p}>0.05)$.

5. sınıftaki öğrencilerin Temel Olaylar ölçütünden aldıkları puanların ortalaması $\bar{X}=2.17,6$. sınıftaki öğrencilerin puanlarının ortalaması $\bar{X}=1.97$, 7. sınıftaki öğrencilerin puanlarının ortalaması $\bar{X}=1.67$ ve 8 . sınıftaki öğrencilerin puanlarının ortalaması $\bar{X}=1.80$ 'dir. Ortalama puanlar incelendiğinde farklı sınıf düzeylerindeki öğrencilerin Temel Olaylar ölçütünde "orta" düzeyde başarım ortaya koydukları görülmektedir. Kruskal Wallis testi sonuçları incelendiğinde öğrencilerin temel olaylar puanları arasında sınıf düzeyine göre anlamlı düzeyde fark olmadığı belirlenmiştir $(\chi 2=2.523, \mathrm{p}>0.05)$.

5. sınıftaki öğrencilerin Sonuç ölçütünden aldıkları puanların ortalaması $\bar{X}=1.83,6$. sınıftaki öğrencilerin puanlarının ortalaması $\bar{X}=1.67$, 7. sınıftaki öğrencilerin puanlarının ortalaması $\bar{X}$ $=1.57$ ve 8. sınıftaki öğrencilerin puanlarının ortalaması $\bar{X}=1.83$ 'tür. Ortalama puanlar incelendiğinde 7. sınıftaki öğrencilerin sonuç ölçütünde "zayıf", diğer sınıftaki öğrencilerin ise "orta" düzeyde başarım ortaya koydukları görülmektedir. Kruskal Wallis testi sonuçları incelendiğinde öğrencilerin sonuç puanları arasında sınıf düzeyine göre anlamlı düzeyde fark olmadığı belirlenmiştir ( $\chi 2=.899, \mathrm{p}>0.05)$.

Hatice Kübra Bahçıvan, Gökhan Çetinkaya

Ortaokul öğrencilerinin özetleme başarıları ile özetlemeye yönelik tutumları ve özyeterlik algıları arasındaki ilişki 
5. sınıftaki öğrencilerin Düzen ölçütünden aldıkları puanların ortalaması $\bar{X}=2.44,6$. sınıftaki öğrencilerin puanlarının ortalaması $\bar{X}=2.13$, 7. sınıftaki öğrencilerin puanlarının ortalaması $\bar{X}$ $=2.13$ ve 8 . sinıftaki öğrencilerin puanlarının ortalaması $\bar{X}=2.07$ 'dir. Ortalama puanlar incelendiğinde 5. sınıftaki öğrencilerin Düzen ölçütünde "iyi" düzeyde, diğer sinıftaki öğrencilerin ise "orta" düzeyde başarım ortaya koydukları görülmektedir. Kruskal Wallis testi sonuçları incelendiğinde öğrencilerin düzen ölçütü puanları arasında sınıf düzeyine göre anlamlı düzeyde fark olmadığı belirlenmiştir $(\chi 2=.921, \mathrm{p}>0.05)$.

5. sınıftaki öğrencilerin Öykü Özeti Değerlendirme Dereceli Puanlama Anahtarı'ndan aldıkları puanların ortalaması $\bar{X}=2.07$, 6. sinıftaki öğrencilerin puanlarının ortalaması $\bar{X}=1.96,7$. sınıftaki öğrencilerin puanlarının ortalaması $\bar{X}=1.78$ ve 8 . sınıftaki öğrencilerin puanlarının ortalaması $\bar{X}=1.88$ 'dir. Ortalama puanlar incelendiğinde farklı sınıf düzeylerindeki öğrencilerin "orta" düzeyde başarım ortaya koydukları görülmektedir. Kruskal Wallis testi sonuçları incelendiğinde öğrencilerin öykü özetleme puanları arasında sınıf düzeyine göre anlamlı düzeyde fark olmadığı belirlenmiştir $(\chi 2=.608, p>0.05)$.

\section{Cinsiyete Göre Öğrencilerin Özetleme Başarısı}

Araştırmanın üçüncü sorusu "Öğrencilerin özetleme başarıları cinsiyete göre farklılık göstermekte midir?" biçiminde oluşturulmuştur. Bu soruya yanıt aramak için öğrencilerin "Öykü Özeti Değerlendirme Dereceli Puanlama Anahtarı" ölçütlerine ilişkin puanlarının ortalaması ve özet metnin tamamına ilişkin puanlarının ortalaması cinsiyet değişkenine göre belirlenmiştir. Elde edilen bulgular Tablo 4'te gösterilmektedir:

\section{Tablo 4}

Cinsiyet Değişkenine Göre Öykü Özetleme Puanı Bağımsız Örneklemler t-testi Sonuçları

\begin{tabular}{|c|c|c|c|c|c|c|c|c|}
\hline & Cinsiyet & $\mathrm{N}$ & $\bar{X}$ & $\begin{array}{l}\text { Başarı } \\
\text { Düzeyi }\end{array}$ & Sx & sd & $\mathrm{t}$ & $\mathrm{p}$ \\
\hline \multirow{2}{*}{ Giriş } & Erkek & 52 & 1.69 & Orta & 1.04 & \multirow{2}{*}{106} & \multirow{2}{*}{-1.743} & \multirow{2}{*}{.084} \\
\hline & $\mathrm{Klz}$ & 56 & 2.04 & Orta & 1.01 & & & \\
\hline \multirow{2}{*}{ Temel Olaylar } & Erkek & 52 & 1.71 & Orta & 1.13 & \multirow{2}{*}{106} & \multirow{2}{*}{-1.386} & \multirow{2}{*}{.169} \\
\hline & $\mathrm{Klz}$ & 56 & 2.02 & Orta & 1.17 & & & \\
\hline \multirow{2}{*}{ Sonuç } & Erkek & 52 & 1.62 & Orta & 1.22 & \multirow{2}{*}{106} & \multirow{2}{*}{-.743} & \multirow{2}{*}{.459} \\
\hline & $\mathrm{Klz}$ & 56 & 1.80 & Orta & 1.39 & & & \\
\hline \multirow{2}{*}{ Düzen } & Erkek & 52 & 1.88 & Orta & 1.00 & \multirow{2}{*}{106} & \multirow{2}{*}{-2.811} & \multirow{2}{*}{$.006^{*}$} \\
\hline & $\mathrm{Klz}$ & 56 & 2.43 & İyi & 1.01 & & & \\
\hline \multirow{2}{*}{ Özet } & Erkek & 52 & 1.73 & Orta & 0.99 & \multirow{2}{*}{106} & \multirow{2}{*}{-1.770} & \multirow{2}{*}{.080} \\
\hline & Kız & 56 & 2.07 & Orta & 1.03 & & & \\
\hline
\end{tabular}

${ }^{*} \mathrm{p}<0.05$

Tablo 4 incelendiğinde erkek öğrencilerin Giriş ölçütünden aldıkları puanların ortalaması $\bar{X}$ $=1.69$, kız öğrencilerin puanlarının ortalaması $\bar{X}=2.04$ 'tür. Ortalama puanlar incelendiğinde kız ve erkek öğrencilerin Giriş ölçütünde "orta" düzeyde başarım ortaya koydukları görülmektedir. Bağımsız Örneklemler t-testi sonuçları incelendiğinde kız ve erkek öğrencilerin Giriş puanları arasında anlamlı düzeyde fark olmadığı belirlenmiştir ( $\mathrm{t}(106)=-1.743, \mathrm{p}>0.05)$.

Erkek öğrencilerin Temel Olaylar ölçütünden aldıkları puanların ortalaması $\bar{X}=1.71$, kız öğrencilerin puanlarının ortalaması $\bar{X}=2.02$ 'dir. Ortalama puanlar incelendiğinde kız ve erkek öğrencilerin Temel Olaylar ölçütünde "orta" düzeyde başarım ortaya koydukları görülmektedir. Bağımsız Örneklemler t-testi sonuçları incelendiğinde kız ve erkek öğrencilerin Temel Olaylar puanları arasında anlamlı düzeyde fark olmadığı belirlenmiștir $(\mathrm{t}(106)=-1.386, \mathrm{p}>0.05)$. 
Erkek öğrencilerin Sonuç ölçütünden aldıkları puanların ortalaması $\bar{X}=1.62$, kız öğrencilerin puanlarının ortalaması $\bar{X}=1.80$ 'dir. Ortalama puanlar incelendiğinde kız ve erkek öğrencilerin Sonuç ölçütünde "orta" düzeyde başarım ortaya koydukları görülmektedir. Bağımsız Örneklemler t-testi sonuçları incelendiğinde kız ve erkek öğrencilerin Sonuç puanları arasında anlamlı düzeyde fark olmadığı belirlenmiştir ( $\mathrm{t}(106)=-.743, \mathrm{p}>0.05)$.

Erkek öğrencilerin Düzen ölçütünden aldıkları puanların ortalaması $\bar{X}=1.88$, kız öğrencilerin puanlarının ortalaması $\bar{X}=2.43$ 'tür. Ortalama puanlar incelendiğinde kız öğrencilerin Düzen ölçütünde "iyi" düzeyde ve erkek öğrencilerin "orta" düzeyde başarım ortaya koydukları görülmektedir. Bağımsız Örneklemler t-testi sonuçları incelendiğinde kız ve erkek öğrencilerin Düzen puanları arasında kız öğrenciler lehine anlamlı düzeyde fark olduğu belirlenmiştir ( $\mathrm{t}$ $(106)=-2.811, \mathrm{p}<0.05)$.

Erkek öğrencilerin Öykü Özeti Değerlendirme Dereceli Puanlama Anahtarı'ndan aldıkları puanların ortalaması $\bar{X}=1.73$, kız öğrencilerin puanlarının ortalaması $\bar{X}=2.07$ 'dir. Ortalama puanlar incelendiğinde kız ve erkek öğrencilerin "orta" düzeyde başarım ortaya koydukları görülmektedir. Bağımsız Örneklemler t-testi sonuçları incelendiğinde kız ve erkek öğrencilerin öykü özetleme puanları arasında anlamlı düzeyde fark olmadığı belirlenmiştir (t (106) =-1.770, $\mathrm{p}>0.05$ ).

\section{Öğrencilerin Özetlemeye Yönelik Tutumları}

Araştırmanın dördüncü sorusu “Öğrencilerin özetlemeye yönelik tutumları nasıldır?” biçiminde oluşturulmuştur. Bu soruya yanıt aramak için öğrencilere "Özetlemeye Yönelik Tutum Ölçeği" uygulanarak elde edilen puanlara ilişkin betimsel istatistikler "Özetlemenin Önemine İnanma" ve "Özet Yapmaktan Hoşlanma" alt boyutlarında ele alınmıștır. Öğrencilerin Özetlemeye Yönelik Tutum Ölçeği'nden aldıkları puanların ortalaması ile Özetlemenin Önemine İnanma ve Özetleme Yapmaktan Hoşlanma alt boyutlarından aldıkları puanların ortalaması belirlenmiştir. Elde edilen bulgular Tablo 5 'te gösterilmektedir.

Tablo 5 incelendiğinde öğrencilerin Özetlemenin Önemine İnanma alt boyutundan aldıkları puanların ortalamasının $\bar{X}=3.98$ olduğu ve özetlemenin önemine "katılıyorum" düzeyinde inandıkları görülmektedir. Öğrenciler Özetlemenin Önemine İnanma alt boyutundaki olumlu maddelere "katılıyorum" düzeyinde yanıt verirken, olumsuz maddelere ise "katılmıyorum" düzeyinde yanıt vermiştir. Bu bulgular öğrencilerin özetlemenin önemine inandıklarını ortaya koymaktadır. Öğrencilerin bu boyutta yer alan "Özetleme, metindeki önemli bilgileri hatırlamama yardımcı olur." biçimindeki dördüncü maddeye katılım düzeyi en yüksek, "Özetlemenin, metnin önemli yerlerini kavramamızda hiçbir faydası yoktur." biçimindeki on ikinci maddeye ise katılım düzeyi en düşük olmuştur.

Tablo 5 incelendiğinde öğrencilerin Özetleme Yapmaktan Hoşlanma alt boyutundan aldıkları puanların ortalaması $\bar{X}=3.41$ olduğu ve özetleme yapmaktan "katılıyorum" düzeyinde hoşlandıkları görülmektedir. Öğrenciler Özetleme Yapmaktan Hoşlanma alt boyutundaki olumlu maddelerden "Özetleme ödevlerini yaparken çabuk motive olurum." maddesine "biraz katılıyorum" düzeyinde, diğer maddelere ise "katılıyorum" düzeyinde yanıt vermiştir. Öğrenciler olumsuz maddelerden "Metnin özetini çlkarmak için yeniden okumaktan hoşlanmam." maddesine "biraz katılmıyorum", diğer olumsuz maddelere ise "katılmıyorum" düzeyinde yanıt vermiştir. Bu bulgular öğrencilerin özetleme yapmaktan hoşlandıklarını ortaya koymaktadır. Öğrencilerin bu boyuttaki maddelerden "Özetleme yaparken ana fikri bulmaktan zevk alırım." biçimindeki yirmi yedinci maddeye katılım düzeyi en yüksek, "Özetleme yapmak bana sıkıcı gelir." biçimindeki yirmi altıncı maddeye ise katılım düzeyi en düşük olmuştur. Özetlemeye yönelik Tutum Ölçeği'nden elde edilen puanların ortalaması ise $\bar{X}=3.66$ olarak bulunmuş ve öğrencilerin tutum düzeylerinin "katılıyorum" düzeyinde olduğu belirlenmiștir. Ölçeğin alt boyutlarından ve tamamından elde edilen puanlar birbiri ile kıyaslandığında ise öğrencilerin en çok özetlemenin önemine inandıkları belirlenmiştir. 


\section{Tablo 5}

Özetlemeye Yönelik Tutum Ölçeğinden Elde Edilen Puanlara İIişkin Betimsel İstatistikler

\begin{tabular}{|c|c|c|c|}
\hline Maddeler & $\overline{\bar{X}}$ & Düzey & $\mathrm{Sx}$ \\
\hline Özetleme, düşünme becerilerimizin gelişimine fayda sağlar. & 3,99 & Katılıyorum & 1,26 \\
\hline $\begin{array}{l}\text { Özetlemenin, metindeki içeriği daha iyi anlamamıza faydası } \\
\text { yoktur. * }\end{array}$ & 2,06 & Katılmıyorum & 1,33 \\
\hline $\begin{array}{l}\text { Özetleme, metindeki önemli bilgileri hatırlamama yardımcı } \\
\text { olur. }\end{array}$ & 4,04 & Katılıyorum & 1,24 \\
\hline Özetleme, anlatma becerilerimin gelişmesine katkı sağlamaz. * & 2,05 & Katılmiyorum & 1,28 \\
\hline Özet çıkarmak, derste verilen metni anlamam için en iyi yoldur. & 3,92 & Katılıyorum & 1,38 \\
\hline Özetleme, anlama becerilerimin gelişmesine katkı sağlar. & 3,99 & Katılıyorum & 1,21 \\
\hline $\begin{array}{l}\text { Özetlemenin, yazma becerilerimin gelişmesine hiçbir faydası } \\
\text { yoktur. * }\end{array}$ & 2,12 & Katılmıyorum & 1,30 \\
\hline Özetleme, yorumlama becerilerimizin gelişimine katkı sağlar. & 3,90 & Katılıyorum & 1,26 \\
\hline $\begin{array}{l}\text { Özetleme, metindeki bilgilerin uzun süre aklımda kalmasına } \\
\text { katkı sağlar. }\end{array}$ & 3,88 & Katılıyorum & 1,19 \\
\hline $\begin{array}{l}\text { Özetlemenin, derste verilen metni anlamamda hiçbir faydası } \\
\text { yoktur.* }\end{array}$ & 1,88 & Katılmıyorum & 1,27 \\
\hline Özetleme, okuma metnini anlamak için en önemli etkinliktir. & 4,02 & Katılıyorum & 1,25 \\
\hline $\begin{array}{l}\text { Özetlemenin, metnin önemli yerlerini kavramamıda hiçbir } \\
\text { faydası yoktur. }{ }^{*}\end{array}$ & 1,86 & Katılmıyorum & 1,13 \\
\hline Özetlemenin Önemine İnanma & 3.98 & Katılıyorum & 0.82 \\
\hline Özetleme yapmaktan hoșlanmam. * & 2,31 & Katılmıyorum & 1,41 \\
\hline $\begin{array}{l}\text { Özetleme ödevlerime dersteki diğer ödevlerim kadar özenli } \\
\text { davranmam. * }\end{array}$ & 2,59 & Katılmıyorum & 1,40 \\
\hline Özet çıkarmak beni heyecanlandırır. & 3,08 & Katılıyorum & 1,42 \\
\hline Metnin özetini çıkarmak için yeniden okumaktan hoşlanmam. * & 2,73 & Biraz Katılıyorum & 1,35 \\
\hline Özetleme ödevlerini yaparken mutlu olurum. & 3,34 & Katılıyorum & 1,32 \\
\hline Özetleme, benim için ilgi çekici bir etkinliktir. & 3,19 & Katılıyorum & 1,33 \\
\hline $\begin{array}{l}\text { Özetleme, benim için dersin daha zevkli işlenmesini sağlayan } \\
\text { bir etkinliktir. }\end{array}$ & 3,19 & Katılıyorum & 1,38 \\
\hline Özetlemede, gereksiz ayrıntıları ayırt ederken sıkılırım. * & 2,53 & Katılmıyorum & 1,33 \\
\hline Özetleme ödevlerini yaparken çabuk motive olurum. & 3,13 & Biraz Katılıyorum & 1,36 \\
\hline $\begin{array}{l}\text { Özetlemek için verilen kaynak metin benim için anlamsız } \\
\text { olduğunda, özetleme yaparken sıkılırım. * }\end{array}$ & 2,51 & Katılmıyorum & 1,37 \\
\hline Özetleme, benim için zevklidir. & 3,50 & Katılıyorum & 1,31 \\
\hline Özetleme ödevlerimi severek yaparım. & 3,56 & Katılıyorum & 1,30 \\
\hline Özetleme beni mutlu eder. & 3,40 & Katılıyorum & 1,24 \\
\hline Özetleme yapmak bana sıkıcı gelir. * & 2,15 & Katılmıyorum & 1,34 \\
\hline Özetleme yaparken ana fikri bulmaktan zevk alırım. & 3,60 & Katılıyorum & 1,34 \\
\hline Özetleme Yapmaktan Hoşlanma & 3.41 & Katılıyorum & 0.85 \\
\hline Özetlemeye Yönelik Tutum & 3.66 & Katılıyorum & 0.74 \\
\hline
\end{tabular}

*Olumsuz maddeler

\section{Sınıf Düzeyine Göre Öğrencilerin Özetlemeye Yönelik Tutumları}

Araştırmanın beşinci sorusu "Öğrencilerin özetlemeye yönelik tutumları sınıf düzeyine göre farklılık göstermekte midir?" biçiminde oluşturulmuştur. Bu soruya yanıt aramak için öğrencilere "Özetlemeye Yönelik Tutum Ölçeği" uygulanarak sınıf düzeylerine göre ölçekten alınan puanların ortalaması ile "Özetlemenin Önemine İnanma" ve "Özet Yapmaktan Hoşlanma" alt boyutlarında sınıf düzeylerine göre puanların ortalaması belirlenmiştir. Elde edilen bulgular Tablo 6'da gösterilmektedir: 
Tablo 6

Sınıf Düzeyine Göre Özetlemeye Yönelik Tutum Ölçeği Kruskal Wallis Testi Sonuçları

\begin{tabular}{|c|c|c|c|c|c|c|c|c|c|c|}
\hline Tutum Ölçeği & Sinif & $\mathrm{N}$ & $\bar{X}$ & Düzey & Sx & Sira Ort. & Sd & $x^{2}$ & $\mathrm{P}$ & $\begin{array}{l}\text { Anlamlı } \\
\text { Fark }\end{array}$ \\
\hline \multirow{4}{*}{$\begin{array}{l}\text { Özetlemenin } \\
\text { Önemine } \\
\text { İnanma }\end{array}$} & 5 & 18 & 4.14 & Katılıyorum & 0.70 & 60.06 & \multirow{4}{*}{3} & \multirow{4}{*}{1.721} & \multirow{4}{*}{.632} & \\
\hline & 6 & 30 & 4.04 & Katıllyorum & 0.80 & 57.00 & & & & \\
\hline & 7 & 30 & 3.94 & Katılıyorum & 0.93 & 54.27 & & & & \\
\hline & 8 & 30 & 3.87 & Katılıyorum & 0.80 & 48.90 & & & & \\
\hline \multirow{4}{*}{$\begin{array}{l}\text { Özetleme } \\
\text { Yapmaktan } \\
\text { Hoşlanma }\end{array}$} & 5 & 18 & 3.84 & Katılıyorum & 0.70 & 69.08 & \multirow{4}{*}{3} & \multirow{4}{*}{$\begin{array}{c}12.72 \\
5\end{array}$} & \multirow{4}{*}{$.007^{*}$} & \\
\hline & 6 & 30 & 3.58 & Katılıyorum & 0.76 & 58.93 & & & & $5-6,7,8$ \\
\hline & 7 & 30 & 3.45 & Katılıyorum & 0.80 & 56.90 & & & & $6-8$ \\
\hline & 8 & 30 & 2.95 & $\begin{array}{c}\text { Biraz } \\
\text { Katillyorum }\end{array}$ & 0.89 & 38.92 & & & & 7-8 \\
\hline \multirow{4}{*}{ Tutum } & 5 & 18 & 3.97 & Katılıyorum & 0.61 & 67.64 & \multirow{4}{*}{3} & \multirow{4}{*}{7.743} & \multirow{4}{*}{.052} & \\
\hline & 6 & 30 & 3.78 & Katılıyorum & 0.69 & 58.15 & & & & \\
\hline & 7 & 30 & 3.67 & Katılıyorum & 0.72 & 54.63 & & & & \\
\hline & 8 & 30 & 3.36 & $\begin{array}{c}\text { Biraz } \\
\text { Katılyyorum }\end{array}$ & 0.79 & 42.83 & & & & \\
\hline
\end{tabular}

$* \mathrm{p}<0.05$

Tablo 6 incelendiğinde 5. sınıfta öğrenim gören öğrencilerin Özetlemenin Önemine İnanma alt boyutundan aldıkları puanların ortalaması $\bar{X}=4.14$, 6. sınıftaki öğrencilerin puanlarının ortalaması $\bar{X}=4.04,7$. sınıftaki öğrencilerin puanlarının ortalaması $\bar{X}=3.94$ ve 8 . sınıftaki öğrencilerin puanlarının ortalaması ise $\bar{X}=3.87$ 'dir. Ortalama puanlar incelendiğinde farklı sınıf düzeyindeki öğrencilerin özetlemenin önemine "katılıyorum" düzeyinde yanıtladıkları ve sınıf düzeyi arttıkça özetlemenin önemine ilişkin olumlu düşüncenin azaldığı görülmektedir. Kruskal Wallis testi sonuçları incelendiğinde öğrencilerin özetlemenin önemine inanma puanları arasında sınıf düzeyine göre anlamlı düzeyde fark olmadığı görülmektedir $(\chi 2=1.721, p>0.05)$.

5. sınıfta öğrenim gören öğrencilerin Özetleme Yapmaktan Hoşlanma alt boyutundan aldıkları puanların ortalaması $\bar{X}=3.84,6$. sınıftaki öğrencilerin puanlarının ortalaması $\bar{X}=3.58,7$. sınıftaki öğrencilerin puanlarının ortalaması $\bar{X}=3.45$ ve 8 . sınıftaki öğrencilerin puanlarının ortalaması ise $\bar{X}=2.95$ 'dir. Ortalama puanlar incelendiğinde 8 . sinıftaki öğrencilerin özetleme yapmaktan "biraz katılıyorum" düzeyinde hoşlandıkları, diğer sınıf düzeyindeki öğrencilerin özetleme yapmaktan "katılıyorum" düzeyinde hoşlandıkları ve sınıf düzeyi arttıkça özetleme yapmaktan daha az hoşlanıldığı görülmektedir. Kruskal Wallis testi sonuçları incelendiğinde öğrencilerin özetleme yapmaktan hoşlanma puanları arasında sınıf düzeyine göre anlamlı düzeyde fark olduğu görülmektedir $(\chi 2=12.725, \quad \mathrm{p}<0.05)$. İkili karşılaştırma sonuçları incelendiğinde ise bu farklılıkların 5. sinıftaki öğrencilerle 6, 7 ve 8. sınıftaki öğrenciler arasında 5. sınıftaki öğrenciler lehine olduğu görülmektedir. Ayrıca 8. sınıftaki öğrencilerle 6 ve 7 . sınıftaki öğrenciler arasında 8. sınıftaki öğrenciler aleyhine olduğu görülmektedir.

5. sınıfta öğrenim gören öğrencilerin Özetlemeye Yönelik Tutum Ölçeği'nden aldıkları puanların ortalaması $\bar{X}=3.97,6$. sınıftaki öğrencilerin puanlarının ortalaması $\bar{X}=3.78,7$. sınıftaki öğrencilerin puanlarının ortalaması $\bar{X}=3.67$ ve 8 . sınıftaki öğrencilerin puanlarının ortalaması ise $\bar{X}=3.36$ 'dir. Ortalama puanlar incelendiğinde 8. sinıftaki öğrencilerin özetlemeye yönelik tutumlarının "biraz katılıyorum" düzeyinde, diğer sınıf düzeyindeki öğrencilerin "katılıyorum" düzeyinde olduğu ve sınıf düzeyi arttıkça özetlemeye yönelik tutumlarının azaldığı görülmektedir. Kruskal Wallis testi sonuçları incelendiğinde öğrencilerin özetlemeye yönelik tutum puanları arasında sınıf düzeyine göre anlamlı düzeyde fark olmadığı görülmektedir $(\chi 2=7.743, p>0.05)$.

\section{Cinsiyete Göre Öğrencilerin Özetlemeye Yönelik Tutumları}

Hatice Kübra Bahçıvan, Gökhan Çetinkaya

Ortaokul öğrencilerinin özetleme başarıları ile özetlemeye yönelik tutumları ve özyeterlik algıları arasındaki ilişki 
Araştırmanın altıncı sorusu "Öğrencilerin özetlemeye yönelik tutumları cinsiyete göre farklılık göstermekte midir?" biçiminde oluşturulmuştur. Bu soruya yanıt aramak için öğrencilere "Özetlemeye Yönelik Tutum Ölçeği" uygulanarak elde edilen puanların ortalaması "Özetlemenin Önemine İnanma” ve "Özet Yapmaktan Hoşlanma” alt boyutlarında ele alınmıștır. Öğrencilerin Özetlemeye Yönelik Tutum Ölçeği'nden elde edilen puanların ortalaması ile Özetlemenin Önemine İnanma ve Özetleme Yapmaktan Hoşlanma alt boyutlarında aldıkları puanların ortalaması cinsiyete göre belirlenmiştir. Elde edilen bulgular Tablo 7'de gösterilmektedir:

\section{Tablo 7}

Cinsiyet Değişkenine Göre Özetlemeye Yönelik Tutum Ölçeği'ne İlişkin Bağımsız Örneklemler t-testi Sonuçları

\begin{tabular}{|c|c|c|c|c|c|c|c|c|}
\hline Tutum Ölçeği & Cinsiyet & $\mathrm{N}$ & $\bar{X}$ & Düzey & $\mathrm{Sx}$ & sd & $\mathrm{t}$ & $\mathrm{p}$ \\
\hline \multirow{2}{*}{$\begin{array}{l}\text { Özetlemenin } \\
\text { Önemine İnanma }\end{array}$} & Erkek & 52 & 3.82 & Katılıyorum & 0.88 & \multirow{2}{*}{106} & \multirow{2}{*}{-2.004} & \multirow{2}{*}{$.048^{*}$} \\
\hline & $\mathrm{K} ı \mathrm{z}$ & 56 & 4.13 & Katılıyorum & 0.73 & & & \\
\hline \multirow{2}{*}{$\begin{array}{l}\text { Özetleme } \\
\text { Yapmaktan } \\
\text { Hoşlanma }\end{array}$} & Erkek & 52 & 3.33 & $\begin{array}{c}\text { Biraz } \\
\text { Katılıyorum }\end{array}$ & 0.86 & \multirow{2}{*}{106} & \multirow{2}{*}{-1.007} & \multirow{2}{*}{.316} \\
\hline & $\mathrm{K} ı \mathrm{Z}$ & 56 & 3.49 & Katılıyorum & 0.84 & & & \\
\hline Özetlemeye & Erkek & 52 & 3.54 & Katılıyorum & 0.76 & \multirow{2}{*}{106} & \multirow{2}{*}{-1.635} & \multirow{2}{*}{.105} \\
\hline Yönelik Tutum & $\mathrm{K} ı \mathrm{z}$ & 56 & 3.78 & Katılıyorum & 0.70 & & & \\
\hline
\end{tabular}

${ }^{*} \mathrm{p}<0.05$

Tablo 7 incelendiğinde erkek öğrencilerin Özetlemenin Önemine İnanma alt boyutundan aldıkları puanların ortalaması $\bar{X}=3.82$, kız öğrencilerin puanlarının ortalaması $\bar{X}=4.13^{\prime}$ tür. Ortalama puanlar incelendiğinde kız ve erkek öğrencilerin özetlemenin önemine "katıllyorum" düzeyinde inandıkları görülmektedir. Bağımsız örneklemler t-testi sonuçları incelendiğinde öğrencilerin özetlemenin önemine inanma puanları arasında kız öğrenciler lehine anlamlı düzeyde fark olduğu görülmektedir $(\mathrm{t}(106)=-2.004, \mathrm{p}<0.05)$.

Erkek öğrencilerin Özetleme Yapmaktan Hoşlanma alt boyutundan aldıkları puanların ortalaması $\bar{X}=3.33$, kız öğrencilerin puanlarının ortalaması $\bar{X}=3.49^{\prime}$ dur. Ortalama puanlar incelendiğinde erkek öğrencilerin özetleme yapmaktan "biraz katılıyorum" düzeyinde, kız öğrencilerin "katılıyorum" düzeyinde hoşlandıkları görülmektedir. Bağımsız örneklemler t-testi sonuçları incelendiğinde öğrencilerin özetleme yapmaktan hoşlanma puanları arasında cinsiyetlerine göre anlamlı düzeyde fark olmadığı görülmektedir $(\mathrm{t}(106)=-1.007, \mathrm{p}>0.05)$.

Erkek öğrencilerin Özetlemeye Yönelik Tutum Ölçeğinden aldıkları puanların ortalaması $\bar{X}$ $=3.54$, kız öğrencilerin puanlarının ortalaması $\bar{X}=3.78^{\prime}$ dir. Ortalama puanlar incelendiğinde kız ve erkek öğrencilerin özetlemeye yönelik tutumlarının "katılıyorum" düzeyinde olduğu görülmektedir. Bağımsız örneklemler t-testi sonuçları incelendiğinde öğrencilerin özetlemeye yönelik tutum puanları arasında cinsiyetlerine göre anlamlı düzeyde fark olmadığı görülmektedir $(\mathrm{t}(106)=-1.635, \mathrm{p}>0.05)$.

\section{Öğrencilerin Özetlemeye Yönelik Özyeterlik Algıları}

Araştırmanın yedinci sorusu "Öğrencilerin özetlemeye yönelik özyeterlik algıları nasıldır?" biçiminde oluşturulmuştur. Bu soruya yanıt aramak için öğrencilere "Özetleme Özyeterlik Ölçeği" uygulanarak elde edilen puanlara ilişkin betimsel istatistikler "Özetleme Amaçlı Okuma" ve "Özet Yazma" alt boyutlarında incelenmiştir. Özetleme Özyeterlik Ölçeği'nde yer alan maddelerin tamamının ortalamasına yer verilmiştir. Öğrencilerin özetleme amaçlı okuma ve özet yazma alt boyutlarında aldıkları puanların ortalaması ve ölçeğin tamamından alınan puanların ortalaması belirlenmiştir. Elde edilen bulgular: Tablo 8'de gösterilmektedir: 
Tablo 8

Özetleme Özyeterlik Ölçeği'nden Elde Edilen Puanlara İlişskin Betimsel İstatistikler

\begin{tabular}{|c|c|c|c|}
\hline Maddeler & $\bar{X}$ & Düzey & Sx \\
\hline 1.Okuduğum metnin ana düşüncesini belirleyebilirim. & 3.65 & Genellikle & 1.03 \\
\hline $\begin{array}{l}\text { 2.Ana düşünceyi destekleyen her bir paragraftaki yan } \\
\text { düşünceyi belirleyebilirim. }\end{array}$ & 2.88 & Kararsızım & 1.08 \\
\hline $\begin{array}{l}\text { 3.Anlatılan olaylarla verilmek istenen iletiyi } \\
\text { ilişsilendirebilirim. }\end{array}$ & 3.78 & Genellikle & 1.26 \\
\hline 4.0kuduğum metnin konusunu belirleyebilirim. & 4.19 & Genellikle & 1.10 \\
\hline 5. Metnin yapısını fark ederim. & 3.38 & Kararsızım & 1.19 \\
\hline Özetleme Amaçlı Okuma & 3.57 & Genellikle & 0.75 \\
\hline 6. Özet metni kendi cümlelerimle oluşturabilirim. & 4.02 & Genellikle & 1.23 \\
\hline $\begin{array}{l}\text { 7. Kaynak metindeki önemli olan olay, durum ve örnekleri } \\
\text { kullanarak özetimi oluşturabilirim. }\end{array}$ & 3.74 & Genellikle & 1.31 \\
\hline $\begin{array}{l}\text { 8.Özetimi metindeki olay akışına ve konu sıralamasına uygun } \\
\text { olarak yazabilirim. }\end{array}$ & 3.59 & Genellikle & 1.20 \\
\hline $\begin{array}{l}\text { 9.Düşüncelerimi uygun sözcükler ve cümleler kullanarak ifade } \\
\text { edebilirim. }\end{array}$ & 3.86 & Genellikle & 1.16 \\
\hline $\begin{array}{l}\text { 10.Kaynak metni yeterince temsil eden bir özet metin } \\
\text { yazabilirim. }\end{array}$ & 3.46 & Genellikle & 1.16 \\
\hline $\begin{array}{l}\text { 11.Özet metnin sayfa düzenini okumayı kolaylaştıracak şekilde } \\
\text { düzenleyebilirim. }\end{array}$ & 3.50 & Genellikle & 1.26 \\
\hline $\begin{array}{l}\text { 12.Özete metnin konusunu yansıtan uygun bir başlık } \\
\text { yazabilirim. }\end{array}$ & 4.17 & Genellikle & 1.20 \\
\hline $\begin{array}{l}\text { 13. Kaynak metindeki bazı ifadeleri birleştirerek tek bir } \\
\text { cümleyle ifade edebilirim. }\end{array}$ & 3.25 & Kararsızım & 1.25 \\
\hline $\begin{array}{l}\text { 14. Uygun bağlaçlar kullanarak akıcı bir özet metin } \\
\text { oluşturabilirim. }\end{array}$ & 3.19 & Kararsızım & 1.34 \\
\hline Özet yazma & 3.64 & Genellikle & 0.73 \\
\hline Toplam puan & 3.62 & Genellikle & 0.67 \\
\hline
\end{tabular}

Tablo 8 incelendiğinde öğrencilerin Özetleme Amaçlı Okuma alt boyutundan aldıkları puanların ortalaması $\bar{X}=3.57$, Özet Yazma alt boyutundan aldıkları puanların ortalaması $\bar{X}=3.64$ ve ölçeğin tamamından aldıkları puanların ortalaması ise $\bar{X}=3.62$ 'dir. Tablo 8'deki ortalama puanlar incelendiğinde öğrencilerin Özetleme Amaçlı Okuma, Özet Yazma ve özetleme konusunda kendilerini yeterli hissetme düzeylerinin "genellikle" düzeyinde olduğu görülmektedir. $\mathrm{Bu}$ bulgular öğrencilerin kendilerini özetleme konusunda yeterli düzeyde algıladıklarını ortaya koymaktadır.

Maddelere ilişkin puanların ortalaması ise 2.88 ile 4.17 arasında değişiklik göstermektedir. Öğrenciler "Ana düşünceyi destekleyen her bir paragraftaki yan düşünceyi belirleyebilirim." maddesinde kendilerini en az düzeyde yeterli hissettiklerini belirtmiştir. Öğrenciler "Kaynak metindeki bazı ifadeleri birleştirerek tek bir cümleyle ifade edebilirim." maddesi ile "Uygun bağlaçlar kullanarak akıcı bir özet metin oluşturabilirim." maddesinde kendilerini çok fazla yeterli görmediklerini ifade etmiştir. Bu üç maddede de öğrenciler kendilerini "kararsızım" düzeyinde yeterli gördüklerini belirtmiştir. Diğer maddelerde ise öğrenciler kendilerini "genellikle" düzeyinde yeterli gördüklerini belirtmiştir. Öğrenciler kendilerini en çok dördüncü madde olan "Okuduğum metnin konusunu belirleyebilirim." maddesi ile on ikinci madde olan "Özete metnin konusunu yansıtan uygun bir başlık yazabilirim." maddelerinde yeterli hissettiklerini belirtmiştir. 


\section{Sınıf Düzeyine Göre Öğrencilerin Özetlemeye Yönelik Özyeterlik Algıları}

Araştırmanın sekizinci sorusu "Öğrencilerin özetlemeye yönelik özyeterlik algıları sınıf düzeyine göre farklılık göstermekte midir? biçiminde oluşturulmuştur. Bu soruya yanıt aramak için öğrencilere "Özetleme Özyeterlik Ölçeği" uygulanarak sınıf düzeylerinde aldıkları puanların ortalaması ile "Özetleme Amaçlı Okuma" ve "Özet Yazma" alt boyutlarında sınıf düzeyi puanlarının ortalaması belirlenmiştir. Elde edilen bulgular Tablo 9'da gösterilmektedir:

Tablo 9

Sınıf Düzeyine Göre Özetleme Özyeterlik Ölçeği Kruskal Wallis Testi Sonuçları

\begin{tabular}{|c|c|c|c|c|c|c|c|c|c|}
\hline Beceri & $\begin{array}{c}\text { Sinıf } \\
\text { Düzeyi }\end{array}$ & $\mathrm{N}$ & $\bar{X}$ & Düzey & Sx & Sira Ort. & $\mathrm{Sd}$ & $\chi^{2}$ & $\mathrm{P}$ \\
\hline \multirow{4}{*}{$\begin{array}{l}\text { Özetleme Amaçlı } \\
\text { Okuma }\end{array}$} & 5 & 18 & 3.73 & Genellikle & 0.72 & 63.83 & \multirow{4}{*}{3} & \multirow{4}{*}{3.341} & \multirow{4}{*}{.342} \\
\hline & 6 & 30 & 3.62 & Genellikle & 0.69 & 54.97 & & & \\
\hline & 7 & 30 & 3.37 & Kararsızım & 0.82 & 47.15 & & & \\
\hline & 8 & 30 & 3.64 & Genellikle & 0.71 & 55.78 & & & \\
\hline \multirow{4}{*}{ Özet Yazma } & 5 & 18 & 3.72 & Genellikle & 0.77 & 57.28 & \multirow{4}{*}{3} & \multirow{4}{*}{1.988} & \multirow{4}{*}{.575} \\
\hline & 6 & 30 & 3.71 & Genellikle & 0.74 & 58.95 & & & \\
\hline & 7 & 30 & 3.47 & Genellikle & 0.79 & 48.15 & & & \\
\hline & 8 & 30 & 3.68 & Genellikle & 0.63 & 54.73 & & & \\
\hline \multirow{4}{*}{ Özyeterlik } & 5 & 18 & 3.73 & Genellikle & 0.69 & 58.81 & \multirow{4}{*}{3} & \multirow{4}{*}{1.984} & \multirow{4}{*}{.576} \\
\hline & 6 & 30 & 3.68 & Genellikle & 0.66 & 57.20 & & & \\
\hline & 7 & 30 & 3.43 & Genellikle & 0.75 & 47.83 & & & \\
\hline & 8 & 30 & 3.67 & Genellikle & 0.57 & 55.88 & & & \\
\hline
\end{tabular}

Tablo 9 incelendiğinde 5. sınıfta öğrenim gören öğrencilerin Özetleme Amaçlı Okuma alt boyutundan aldıkları puanların ortalaması $\bar{X}=3.73$, 6. sınıftaki öğrencilerin puanlarının ortalaması $\bar{X}=3.62$, 7. sınıftaki öğrencilerin puanlarının ortalaması $\bar{X}=3.37$ ve 8 . Sınıftaki öğrencilerin puanlarının ortalaması ise $\bar{X}=3.64$ 'tür. Ortalama puanlar incelendiğinde, 7 . sınıftaki öğrencilerin özetleme amaçlı okuma konusunda kendilerini yeterli hissetme düzeylerinin "kararsızım", diğer sınıf düzeyindeki öğrencilerin ise "genellikle" düzeyinde olduğu görülmektedir. Kruskal Wallis testi sonuçları incelendiğinde öğrencilerin özetleme amaçlı okuma puanları arasında sınıf düzeyine göre anlamlı düzeyde fark olmadığı görülmektedir $(\chi 2=3.341, \mathrm{p}>0.05)$.

5. sınıfta öğrenim gören öğrencilerin Özet Yazma alt boyutundan aldıkları puanların ortalaması $\bar{X}=3.72$, 6. Sinıftaki öğrencilerin puanlarının ortalaması $\bar{X}=3.71$, 7. Sınıftaki öğrencilerin puanlarının ortalaması $\bar{X}=3.47$ ve 8 . Sinıftaki öğrencilerin puanlarının ortalaması ise $\bar{X}$ =3.68'dir. Ortalama puanlar incelendiğinde farklı sınıf düzeyindeki öğrencilerin özet yazma konusunda kendilerini yeterli hissetme düzeylerinin "genellikle" düzeyinde olduğu görülmektedir. Kruskal Wallis testi sonuçları incelendiğinde öğrencilerin özet yazma puanları arasında sınıf düzeyine göre anlamlı düzeyde fark olmadığı görülmektedir ( $\chi 2=1.988, p>0.05)$.

5. sınıfta öğrenim gören öğrencilerin Özetleme Özyeterlik Ölçeği'nden aldıkları puanların ortalaması $\bar{X}=3.73$, 6. Sinıftaki öğrencilerin puanlarının ortalaması $\bar{X}=3.68$, 7. Sinıftaki öğrencilerin puanlarının ortalaması $\bar{X}=3.43$ ve 8 . Sınıftaki öğrencilerin puanlarının ortalaması ise $\bar{X}=3.67$ 'dir. Ortalama puanlar incelendiğinde öğrencilerin özetleme konusunda kendilerini yeterli hissetme düzeylerinin "genellikle" düzeyinde olduğu görülmektedir. Kruskal Wallis testi sonuçları incelendiğinde öğrencilerin özetlemeye yönelik özyeterlik puanları arasında sınıf düzeyine göre anlamlı düzeyde fark olmadığı görülmektedir $(\chi 2=1.984, p>0.05)$. 


\section{Cinsiyete Göre Öğrencilerin Özetlemeye Yönelik Özyeterlik Algıları}

Araştırmanın dokuzuncu sorusu "Öğrencilerin özetlemeye yönelik özyeterlik algıları cinsiyete göre farklılık göstermekte midir?" biçiminde oluşturulmuştur. Bu soruya yanıt aramak için öğrencilere "Özetleme Özyeterlik Ölçeği” uygulanarak elde edilen puanların ortalaması "Özetleme Amaçlı Okuma" ve "Özet Yazma" alt boyutlarında incelenmiştir. Özetleme Özyeterlik Ölçeği'nde yer alan maddelerin tamamının ortalaması cinsiyet değişkenine göre ele alınmıştır. Öğrencilerin Özetleme Amaçlı Okuma ve Özet Yazma alt boyutlarında aldıkları puanların ortalaması ve ölçeğin tamamından alınan puanların ortalaması cinsiyet değişkenine göre belirlenmiștir. Elde edilen bulgular Tablo 10'da gösterilmektedir:

Tablo 10

Cinsiyet Değişkenine Göre Özyeterlik Ölçeğine İlişkin Bağımsız Örneklemler t-testi Sonuçları

\begin{tabular}{|c|c|c|c|c|c|c|c|c|}
\hline $\begin{array}{l}\text { Özyeterlik } \\
\text { Ölçeği }\end{array}$ & Cinsiyet & $\mathrm{N}$ & $\bar{X}$ & Düzey & Sx & sd & $\mathrm{t}$ & $\mathrm{p}$ \\
\hline \multirow{2}{*}{$\begin{array}{l}\text { Özetleme } \\
\text { Amaçlı Okuma }\end{array}$} & Erkek & 52 & 3.59 & Genellikle & 0.74 & \multirow{2}{*}{106} & \multirow{2}{*}{.193} & \multirow{2}{*}{.847} \\
\hline & $\mathrm{Kiz}$ & 56 & 3.56 & Genellikle & 0.75 & & & \\
\hline \multirow{2}{*}{ Özet Yazma } & Erkek & 52 & 3.66 & Genellikle & 0.61 & \multirow{2}{*}{106} & \multirow{2}{*}{.263} & \multirow{2}{*}{.793} \\
\hline & $\mathrm{Kiz}$ & 56 & 3.62 & Genellikle & 0.83 & & & \\
\hline \multirow{2}{*}{ Özyeterlik } & Erkek & 52 & 3.63 & Genellikle & 0.60 & \multirow{2}{*}{106} & \multirow{2}{*}{.260} & \multirow{2}{*}{.795} \\
\hline & $\mathrm{Kiz}$ & 56 & 3.60 & Genellikle & 0.74 & & & \\
\hline
\end{tabular}

Tablo 10 incelendiğinde erkek öğrencilerin Özetleme Amaçlı Okuma alt boyutundan aldıkları puanların ortalaması $\bar{X}=3.59$, kız öğrencilerin puanlarının ortalaması $\bar{X}=3.56$ 'dır. Ortalama puanlar incelendiğinde kız ve erkek öğrencilerin özetleme amaçlı okuma konusunda kendilerini yeterli hissetme düzeylerinin "genellikle" düzeyinde olduğu görülmektedir. Bağımsız örneklemler t-testi sonuçları incelendiğinde öğrencilerin özetleme amaçlı okuma puanları arasında cinsiyetlerine göre anlamlı düzeyde fark olmadığı görülmektedir ( $\mathrm{t}(106)=.193, \mathrm{p}>0.05)$.

Erkek öğrencilerin Özet Yazma alt boyutundan aldıkları puanların ortalaması $\bar{X}=3.66$, kız öğrencilerin puanlarının ortalaması $\bar{X}=3.62$ 'dir. Ortalama puanlar incelendiğinde kız ve erkek öğrencilerin özet yazma konusunda kendilerini yeterli hissetme düzeylerinin "genellikle" düzeyinde olduğu görülmektedir. Bağımsız örneklemler t-testi sonuçları incelendiğinde öğrencilerin özet yazma puanları arasında cinsiyetlerine göre anlamlı düzeyde fark olmadığı görülmektedir ( $\mathrm{t}(106)=.263, \mathrm{p}>0.05)$.

Erkek öğrencilerin Özetleme Özyeterlik Ölçeği'nden aldıkları puanların ortalaması $\bar{X}=3.63$, kız öğrencilerin puanlarının ortalaması $\bar{X}=3.60$ 'ır. Ortalama puanlar incelendiğinde kız ve erkek öğrencilerin özetleme konusunda kendilerini yeterli hissetme düzeylerinin "genellikle" düzeyinde olduğu görülmektedir. Bağımsız örneklemler t-testi sonuçları incelendiğinde öğrencilerin özetleme özyeterlik puanları arasında cinsiyetlerine göre anlamlı düzeyde fark olmadığı görülmektedir ( $\mathrm{t}(106)=.260, \mathrm{p}>0.05)$.

\section{Öğrencilerin Özetleme Başarıları ile Özetlemeye Yönelik Tutum ve Özyeterlik Algıları Arasındaki İlişki}

Araştırmanın onuncu sorusu "Öğrencilerin özetleme başarıları ile özetlemeye yönelik tutum ve özetlemeye yönelik özyeterlik algı puanları arasında anlamlı bir ilişki var mıdır?" biçiminde oluşturulmuştur. Bu soruya yanıt aramak için öğrencilerin özetleme başarıları "Öykü Özeti Değerlendirme Dereceli Puanlama Anahtarı" ölçütlerine ilişkin Giriş, Temel Olaylar, Sonuç ve Düzen becerileri belirlenmiştir. Öğrencilerin özetleme başarıları ile Özetleme Amaçlı Okuma ve Özet Yazma alt boyutlarında belirlenen özetleme özyeterlik puanları ile Özetlemenin Önemine İnanma ve Özetleme Yapmaktan Hoşlanma alt boyutlarında belirlenen özetlemeye yönelik tutumları arasındaki ilişki incelenmiştir. Elde edilen bulgular Tablo 11'de gösterilmektedir: 


\section{Tablo 11}

Özetleme Başarıları ile Özetlemeye Yönelik Tutum ve Özetleme Özyeterlik Puanları Arasındaki Pearson Korelasyon Katsayıları

\begin{tabular}{|c|c|c|c|c|c|}
\hline & \multicolumn{4}{|c|}{ Özetleme Başarıları } & \multirow{2}{*}{ Toplam } \\
\hline & Giriş & Temel Olaylar & Sonuç & Düzen & \\
\hline Özetleme Amaçlı Okuma & $.420^{* *}$ & $.473^{* *}$ & $.567^{* *}$ & $.446^{* *}$ & $.533^{* *}$ \\
\hline Özet Yazma & $.498^{* *}$ & $.461^{* *}$ & $.544^{* *}$ & $.466^{* *}$ & $.548^{* *}$ \\
\hline Özetleme Özyeterlik & $.513^{* *}$ & $.508^{* *}$ & $.603^{* *}$ & $.501^{* *}$ & $.592^{* *}$ \\
\hline Özetlemenin Önemine İnanma & $.369^{* *}$ & $.400^{* *}$ & $.462^{* *}$ & $.316^{* *}$ & $.434^{* *}$ \\
\hline Özetleme Yapmaktan Hoşlanma & .140 & .186 & .177 & .137 & .179 \\
\hline Özetlemeye Yönelik Tutum & $.272^{* *}$ & $.317^{* *}$ & $.342^{* *}$ & $.244^{*}$ & $.330^{* *}$ \\
\hline
\end{tabular}

Tablo 11 incelendiğinde öğrencilerin Giriş, Temel Olaylar, Sonuç ve Düzen becerileri ile Özetleme Amaçlı Okuma, Özet Yazma ve Özetleme Özyeterlik puanları arasında olumlu yönde ve orta düzeyde anlamlı ilişki olduğu görülmektedir. Öğrencilerin Özetleme Başarıları ile Özetleme Amaçlı Okuma, Özet Yazma ve Özetleme Özyeterlik puanları arasında olumlu yönde ve orta düzeyde anlamlı ilişki olduğu görülmektedir.

Öğrencilerin Giriş, Temel Olaylar, Sonuç ve Düzen becerileri ile Özetlemenin Önemine İnanma puanları arasında olumlu yönde ve orta düzeyde anlamlı ilişki olduğu belirlenirken Özetleme Yapmaktan Hoşlanma puanları ile bu beceriler arasında anlamlı ilişkilerin olmadığı tespit edilmiştir. Öğrencilerin Özetlemeye Yönelik Tutum puanları ile Temel Olaylar ve Sonuç becerileri arasında olumlu yönde ve orta düzeyde; Giriș ve Düzen becerileri arasında ise olumlu yönde ve düşük düzeyde anlamlı ilişkilerin olduğu belirlenmiştir. Öğrencilerin Özetleme Başarıları ile Özetlemenin Önemine İnanma ve Özetlemeye Yönelik Tutum puanları arasında ise olumlu yönde ve orta düzeyde anlamlı ilişki olduğu belirlenmiştir.

\section{TARTIŞMA ve SONUÇ}

Ortaokul öğrencilerinin özetleme başarıları ile özetleme özyeterlik algıları ve özetleme tutumları arasındaki ilişkiyi belirlemeyi amaçlayan bu araştırmada öğrencilerin özetleme başarıları, özetleme tutumları ve özetleme özyeterlik algılarının sınıf düzeyi ve cinsiyet değişkenlerine göre farklılaşıp farklılaşmadığı incelenmiştir.

Özet metinde yer alacak bilgiye ulaşmak için bireyin kaynak metnin önermelerinden yönelimle silme, genelleme ve bütünleștirme eylemlerini işleterek büyük ölçekli yapıyı oluşturması gerekir (Kintsch \& van Dijk, 1978). Yapılan çalışmaların sonuçları ise her eğitim düzeyinde öğrencilerin kaynak metinden doğrudan alıntı yaptığı, özetleme amaçlı okuma ve özet metin yazma sürecinde işletilmesi gereken stratejileri işletme becesinin zayıf olduğu yönündedir (Çılkrıkçı, 2008; Susar Kırmızı \& Akkaya, 2011; Eyüp, Stebler, \& Yurt, 2012; Karatay \& Okur, 2012). Öğrencilerin özetleme başarılarına ilişkin çözümleme sonucunda, öğrencilerin giriş, temel olaylar, sonuç, düzen ölçütlerine ve özet metnin bütüne ilişkin özetleme başarılarının orta düzeyde olduğu görülmüştür.

Brown ve Day (1983) yaş ilerledikçe ve sınıf düzeyi arttıkça uygun silme becerilerinin arttı̆̆ını belirtir. Brown ve Day'in (1983) çalışmasının bulguları beşinci sınıf öğrencilerinin bilgiyi aşırı silme eğiliminde oldukları ve özetlerini kısaltırken sıklıkla önemli bilgiyi bile gözardı ettikleri yönündedir. Bunun yanında çalışmada lise ve üzeri eğitim düzeyinden öğrencilerin yalnızca önemsiz ya da yinelenen önermeleri silerek daha yetkin bir beceri sergiledikleri sonucuna ulaşılmıştır. Çetinkaya, Şentürk ve Dikici'nin (2020) çalışmasının sonuçlarına göre sınıf düzeyi değişkenine göre özetleme genel başarımında anlamlı fark oluşmazken özetleme başarımı alt boyutlarının temel olay ve düzen-yazım puanları açısından anlamlı fark vardır. Temel olay Hatice Kübra Bahçıvan, Gökhan Çetinkaya Ortaokul öğrencilerinin özetleme başarıları ile özetlemeye yönelik tutumları ve özyeterlik algıları arasındaki ilişki 
boyutunda dokuzuncu sınıf ile üniversite birinci sınıf öğrencileri arasında, düzen-yazım boyutunda da beşinci sınıf-dokuzuncu sınıf ve beşinci sınıf-üniversite birinci sınıflar arasında anlamlı fark olduğu görülmüștür. İlgili çalışmada eğitim düzeyinin özetleme stratejilerini kullanma ve özetleme başarımı konusunda çok anlamlı bir değişken olmadığı hatta üst sınıf düzeylerinde kullanımın ve başarımın daha düşük olduğuna ilişkin görünüm olduğu sonucu vurgulanmaktadır. Bu çalışmanın sonuçları da özet metnin giriş, temel olaylar, sonuç ve düzen boyutlarına ve özet metnin bütününe ilişkin genel başarıda sınıf düzeyi değișkenine göre anlamlı fark olmadığını göstermiştir. Ancak özet metin yazma başarısı ve düzen-yazım ölçütü açısından beşinci sınıf öğrencilerinin daha yüksek puan ortalamasına sahip olduğu saptanmıştır. Dikkat çeken bir diğer bulgu özet metnin sonuç bölümünü yazma konusunda diğer sınıf düzeyleri orta düzeyde bașarı gösterirken yedinci sınıf öğrencilerinin zayıf bir başarım ortaya koymuş olmasıdır. Bu sonuçlar grubun kendi özelliklerinden kaynaklanacağı gibi eğitim ortamlarında özetlemeye dönük verilen eğitimin içeriğinden de kaynaklanabilir. Çünkü Türkçe ders kitaplarında özetleme becerilerine dönük doğrudan etkinlikler yetersizdir (Fidan \& Gerçek, 2017). Doğrudan özetleme stratejileriyle örüntülenmiş etkinlikler öğrencilerin özetleme becerilerinin geliştirilmesi açısından etkili olabilir (Konuk, Ören, Benzer, \& Sefer, 2016).

Birçok çalışmada cinsiyetin özetleme başarısı üzerinde etkisi olup olmadığı sorgulanmıştır. Yapılan çalışmaların bir bölümü kız öğrencilerin (Ülper \& Okuyan, 2010; Başkan, 2019; Eroğlu, 2019; Çetin \& Bulut, 2020; Çetinkaya, Şentürk \& Dikici, 2020) bir bölümü erkek öğrencilerin (Erdem, 2012) daha başarılı olduğuna bir bölümü de cinsiyetin etkisi olmadığına (Pakzadian \& Rasekh, 2012; Bıyıklı \& Doğan, 2015; Görgen \& Altıntaş, 2015; Zenci, 2020) işaret etmektedir. Bu çalışmanın sonuçlarına göre özet metnin giriş, temel olaylar ve sonuç bölümlerini yazma ve özet metnin genel puan ortalamaları açısından kız ve erkek öğrenciler arasında anlamlı bir fark bulunmamıştır. Özet metnin düzen boyutunda ise kız öğrenciler lehine anlamlı fark olduğu belirlenmiştir. Öte yandan, kız öğrencilerin özet metin yazma puan ortalamalarının erkek öğrencilerden daha yüksek olduğu görülmüştür. Her ne kadar birçok çalışmanın sonuçları kız öğrencilerin özetleme başarımının erkek öğrencilerden yüksek olduğu sonucunda yoğunlaşsa da bu değişkenin mutlak bir etkisi olduğu söylenemez. Bu sonucun nedeni gruba özgü bir özellik olarak açlklanabilir.

Daha önceden de anıldığı gibi tutum belirli bir varlığı hoşlanma ya da hoşlanmama aralığında değerlendirerek derecelendiren ruhsal bir eğilimdir (Egly \& Chaiken, 1993). Tutum öğrencilerin okuryazarlık gelişiminde önemli bir duyuşsal niteliktir. Tutum öğrenme güdüsünü etkileyerek öğrencilerin dilsel beceri alanına ilişkin göreve yaklaşımlarına yön verebilir. Öğrencilerin özetlemeye yönelik tutumlarına ilişkin çözümleme sonuçları öğrencilerin özetlemenin önemine inandıklarını ve özetleme yapmaktan hoşlandıklarını göstermiştir. Ölçekte yer alan özetleme ödevlerini yaparken çabuk güdülenirim maddesine biraz katılıyorum yanıtını vermeleri dikkat çekmektedir. Bu durum öğrencilerin özetleme ödevinden çok hoşlanmadıkları ve özetleme ödevinin yararına inanmadıkları biçiminde yorumlanabilir. Olumlu tutuma sahip bireyler özete önemli bir değer yükler. Değerli görülen şeyler bireylerin güdüsünü artırır. Tutuma bağlı oluşan güdü, bireylerin dikkat geliştirmesini sağladığından okunan metnin anlaşılmasında önemli bir işlev görür (Devine, 1989; Akt. Bayat \& Çetinkaya, 2018).

Öğrencilerin özetlemeye yönelik tutumlarının sınıf düzeyi değișkeni açısından değișip değişmediğine ilişkin yapılan Kruskal Wallis Testi sonuçları ölçeğin özetlemenin önemine inanma alt boyutunda anlamlı fark olmadığını göstermiştir. Sınıf düzeyi arttıkça özetlemenin önemine ilişkin olumlu düşüncenin azalması dikkat çeken bir durumdur. Öte yandan, özetleme yapmaktan hoşlanma alt boyutunda sınıf düzeyine göre anlamlı fark olduğu görülmüștür. $\mathrm{Bu}$ boyutta da sınıf düzeyi arttıkça özetleme yapmaktan daha az hoşlanıldığı görülmüştür. Özetlemeye yönelik tutumda sınıf düzeyi açısından anlamlı fark olmadığı sınıf düzeyi arttıkça olumlu tutumun azaldığı görülmüştür. McKenna, Kear ve Ellsworth (1995), çalışmasında çocuklar büyüdükçe olumlu tutumların olumsuza dönüştüğünü ortaya koymuştur. Eğitim düzeyi arttıkça öğrencilerin olumlu tutumlarının olumsuza dönüşmesinin nedeni öğrencilere verilen 
görevlerin daha çok boyut içermesi ve bunun sonucu olarak daha fazla bilişsel yük gerektirmesi olabilir.

Öğrencilerin özetlemeye yönelik tutumlarının cinsiyet açısından değişip değişmediğine ilişkin yapılan bağımsız örneklemler t-testi sonuçları özetlemenin önemine inanma boyutunda kız öğrenciler lehine anlamlı fark olduğunu göstermiştir. Öte yandan, özetleme yapmaktan hoşlanma boyutunda cinsiyet açısından anlamlı bir fark bulunmamıştır. Özetlemeye yönelik tutum puanları arasında da cinsiyete göre anlamlı fark bulunmamıștır. Eroğlu'nun (2019) çalışmasının sonuçlarına göre özetlemenin önemine inanma, özetleme yapmaktan hoşlanma ve ölçeğin tamamında kız öğrenciler lehine anlamlı bir fark vardır.

Özyeterliği daha yüksek olan öğrenciler, akademik açıdan zorlayıcı görevleri seçmeye, bu tür görevlere daha fazla çaba sarf etmeye ve daha düşük özyeterliliğe sahip akranlarına göre başarıyı daha sık deneyimlemeye daha yatkındır (Zumbrunn, Broda, Varier, \& Conklin, 2019). Öğrencilerin özetleme özyeterliklerinin özetleme amaçlı okuma, özet yazma alt boyunda ve ölçeğin tamamında yüksek olduğu görülmüştür. Özyeterlik algısı ölçeğinin özetleme amaçlı okuma alt boyutunun iki maddesinde öğrencilerin kendini orta derecede yeterli algıladıkları görülmüștür. Buna göre öğrenciler kendilerini ana düşünceyi destekleyen her bir paragraftaki yan düşünceyi belirleme ve metnin yapısını fark etme konusunda çok yeterli görmemektedir. Özet yazma alt boyutunun iki maddesinde de benzer olarak öğrencilerin kendini çok yeterli bulmadıkları görülmüştür. Buna göre öğrenciler kendilerini kaynak metindeki bazı ifadeleri birleştirerek tek bir tümceyle söze dökme ve uygun bağlaçlar kullanarak akıcı bir özet metin oluşturma konusunda çok yeterli görmemektedir.

Öğrencilerin özetlemeye yönelik özyeterlik algılarının sınıf düzeyi açısından değişip değişmediğine ilişkin yapılan Kruskal Wallis Testi sonuçları özetleme amaçlı okuma, özet yazma alt boyutlarında ve ölçeğin tamamında anlamlı fark olmadığını göstermiştir. Yedinci sınıf öğrencilerinin ölçeğin her iki boyutunda ve tamamında diğer sınıflara göre özyeterliklerinin düşük olduğu, yedinci sınıf dışarıda tutulduğunda sınıf düzeyi yükseldikçe özetleme özyeterlik algısının düştüğü görülmüştür. Anımsanacağı gibi çalışmanın özetlemeye yönelik tutumun sınıf değişkeni açısından görünümü de sınıf düzeyi yükseldikçe olumlu tutumun azalması biçimindeydi. Bu durumun nedeni sınıf düzeyi arttıkça öğrencilerin üstesinden gelmesi gereken görevlerin daha karmaşık ve zorlu olması olabilir.

Öğrencilerin özetlemeye yönelik özyeterlik algılarının cinsiyet açısından değişip değişmediğine ilişkin yapılan bağımsız örneklemler t-testi sonuçları özetleme amaçlı okuma, özet yazma alt boyutlarında ve ölçeğin tamamında anlamlı fark olmadığını göstermiştir. Ölçeğin her iki boyutunda ve tamamında erkek öğrencilerin özyeterlik algılarının kız öğrencilerin algılarının biraz üstünde olduğu bulunmuştur. Akademik başarı ile özyeterlik arasındaki ilişki üzerine yapılan çalışmalar da genel olarak cinsiyetin anlamlı bir değișken olmadığı yönündedir (Hampton \& Mason, 2003; Usher \& Pajares, 2006).

Özetleme başarıları ile özetlemeye yönelik tutum ve özetleme özyeterlik algısı arasında olumlu yönde orta düzeyde anlamlı ilişki bulunmuştur. Özet metnin dört alt boyutuna ilişkin başarı puanları ile tutum ve özyeterlik algısı ölçeklerinin alt boyutları arasında da olumlu yönde orta düzeyde anlamlı ilişki olduğu saptanmıştır. Yani özet metnin giriş, temel olaylar, sonuç ve düzen boyutlarını yapılandırma başarısı ile özetlemenin önemine inanma ve özetleme yapmaktan hoşlanma arasında olumlu yönde orta düzeyde anlamlı bir ilişki vardır. Benzer olarak, özetleme amaçlı okuma ve özet yazma özyeterlik algısı ile özet metnin giriş, temel olaylar, sonuç ve düzen boyutlarını yapılandırma başarısı arasında olumlu yönde orta düzeyde ilişki vardır. Daha önceden de belirtildiği gibi öğrencilerin özetleme başarıları, özetlemeye yönelik tutumları ve özetleme özyeterlik algıları arasındaki ilişkiye yönelik bir çalışma yer almamaktadır. Özetleme ediminin anlatma becerisini içermesi bakımından bu çalışmanın sonuçları ile Bulut'un (2017) yazmaya yönelik tutumun ve özyeterliğin özetlemeye etkisi konulu çalışmasının sonuçları ele alınabilir. Bulut'un çalışmasının sonuçları yazma tutumu ile yazma özyeterlik algılarının 
doğrudan ve anlamlı bir biçimde özet yazmayı etkilediği yönündedir. Sonuçlar Bandura'nın (1986) sosyal bilişsel kuramında özyeterliliğin varsayılmış rolünü desteklemektedir.

Özetlemek zor bir beceridir çünkü okuyucuların kavrama durumunu etkin olarak izlemesi ve aynı anda önemli bilgileri belirlemesi, önemsiz bilgiyi silmesi ve ana düşünceleri paragraflara ve bölümlere bütünleştirmesini gerekli kllar (Stevens, Park, \& Vaughn, 2019). Öğrencilerin bu zorlu görevin üstesinden gelebilmesi için özetlemenin önemine inanması ve özet metin oluşturmaktan hoşlanması gerekir. Bunun yanında özyeterliği daha yüksek olan öğrenciler, akademik açıdan zorlayıcı görevleri seçmeye, bu tür görevlere daha fazla çaba sarf etmeye ve daha düşük özyeterliliğe sahip akranlarına göre başarıyı daha sık deneyimlemeye daha yatkındır. Bu yüzden öğretim sürecinde öğrencilerin özyeterliklerini besleyen özetleme etkinlikleri yapılmalıdır.

\section{Araştırmanın Sınırlılıkları}

$\mathrm{Bu}$ araştırma erişim kolaylığı bulunan ortaokul öğrencileri ile yapılmıştır. Araştırmada veri toplamak için ölçekler kullanılmıştır. Araştırma, katılımcıların ölçeklere verdikleri yanıtlar ile sinırlıdır.

\section{Destek ve Teşekkür}

Yazarlar olarak, araştırmanın gerçekleştirilmesi sürecine yönelik herhangi bir destek ya da teșekkür beyanımız bulunmamaktadır.

\section{Araștırmacıların Katkı Oranı}

Araştırmanın yazarları araştırmanın tüm süreçlerine eşit derecede katkı sağlamıştır.

\section{Çatışma Beyanı}

Araştırmanın yazarları olarak herhangi bir çıkar/çatışma beyanımız olmadığını ifade ederiz.

\section{Yayın Etiği Beyanı}

$\mathrm{Bu}$ araștırmanın planlanmasından, uygulanmasına, verilerin toplanmasından verilerin analizine kadar olan tüm süreçte "Yükseköğretim Kurumları Bilimsel Araştırma ve Yayın Etiği Yönergesi" kapsamında uyulması belirtilen tüm kurallara uyulmuştur. Yönergenin ikinci bölümü olan "Bilimsel Araştırma ve Yayın Etiğine Aykırı Eylemler" başlı̆̆ı altında belirtilen eylemlerden hiçbiri gerçekleştirilmemiştir.

$\mathrm{Bu}$ çalışmanın yazım sürecinde bilimsel, etik ve alıntı kurallarına uyulmuş; toplanan veriler üzerinde herhangi bir tahrifat yapılmamış ve bu çalışma herhangi başka bir akademik yayın ortamına değerlendirme için gönderilmemiştir.

\section{Etik kurul izin bilgileri}

Etik değerlendirmeyi yapan kurul adı: Niğde Ömer Halisdemir Üniversitesi

Etik değerlendirme kararının tarihi: 01.07.2020

Etik değerlendirme belgesi sayı numarası: 2020/06-02

\section{KAYNAKÇA}

Abasıyanık, S. F. (2016). Mahalle kavgası. Ankara: İș Bankası Kültür Yayınları.

Alexander, J. E., \& Filler, R. C. (1976). Attitudes and reading. Newark, DE: InterNational Reading Association.

Altunkaya, H. (2018). Ortaokul 8. sınıf öğrencilerinin okur özyeterlikleri ile okuduklarını anlama becerileri arasındaki ilişki. Ana Dili Eğitimi Dergisi, 6(1), 202- 219.

Bahap Kudret, Z., \& Baydık, B. (2016). Başarılı ve başarısız dördüncü sınıf okuyucularının okuduğunu anlama ve özetleme becerileri. Ankara Üniversitesi Eğitim Bilimleri Fakültesi Özel Eğitim Dergisi, 17(3), 317-346. 
Bandura, A. (1982). Self-efficacy mechanism in human agency. American Psychologist, 37(2), 122-147. https://doi.org/10.1037/0003-066X.37.2.122

Bandura, A. (1986): Social foundations of thought and action: A social cognitive theory. Englewood Cliffs, NJ: Prentice-Hall.

Bandura, A. (1993). Perceived self- efficacy in cognitive development and functioning. Educational Psychologist, 28(2), 117-148.

Başkan, A. (2019). Yedinci sınıf öğrencilerinin öyküleyici metin yazma becerilerinin çeșitli değişkenler açısından incelenmesi. Bolu Abant İzzet Baysal Üniversitesi Eğitim Fakültesi Dergisi, 19(2), 453-467.

Bayat, N., \& Çetinkaya, G. (2018). Ortaokul öğrencilerinin okuma alışkanlıkları ve tercihleri. İlköğretim Online, 17(2), 984-1001.

Bıyıklı, C. ve Doğan, N. (2015). Öğrenme stratejilerini tekrar amacıyla kullanmanın akademik başarıya etkisi. Eğitim ve Bilim, 40(181), 311-327.

Boakye, N. A. (2015). The relationship between self-efficacy and reading proficiency of first year students: An exploratory study. Reading \& Writing, 6(1), 1-9.

Bong, M. (2006). Asking the right question: How confident are you that you could successfully perform these tasks. F. Pajares \& T. Urdan (Ed.) içinde, Self-efficacy beliefs of adolescents (ss. 287-305). Greenwich, CT: Information Age.

Brown, A. L., \& Day, J. D. (1983). Macrorules for summarizing texts: The development of expertise. Journal of Verbal Learning and Verbal Behavior, 22, 1-14. https://doi.org/10.1016/S0022-5371(83)80002-4

Bulut, P. (2017). The effect of primary school students' writing attitudes and writing self- effecacy beliefs on their summary writing achievement. International Electronic Journal of Elementary Education, $10(2), 281-285$.

Büyüköztürk, Ș. (2012). Eğitimde bilimsel araştırma yöntemleri. Pegem Yayıncıllk.

Chiang, E., Therriault, D., \& Franks, B. (2010). Individual differences in relative metacomprehension accuracy: variation within and across task manipulations. Metacognition Learning, 5, 121-135. https://doi.org/10.1007/s11409-009-9052-6

Clark, K. A. (2012). Student attitudes toward writing and the effects on writing progress. (Yayınlanmamış yüksek lisans tezi). The College at Brocport: State University of New York.

Çetin, Ö., \& Bulut, K. (2020). 8. sınıf öğrencilerinin hikaye edici metinleri özetleme becerilerinin bazı değişkenlere göre incelenmesi. Türkiye Eğitim Dergisi, 5(1), 69-85. https://dergipark.org.tr/tr/pub/turkegitimdergisi/issue/54397/732260

Çetinkaya, G., \& Polat Demir, B. (2017). H. Ülper (Ed.) içinde, Özetlemeye yönelik tutum ölçeğinin geliștirilmesi: Güvenirlik ve geçerlik (ss. 206-221). 9. uluslararası Türkçenin eğitim-öğretimi kurultayı bildirileri. Pegem Akademi.

Çetinkaya, G., Şentürk, R., \& Dikici, A. (2020). Özetleme stratejilerinin kullanımı ile özetleme başarımı arasındaki ilişki. Dil Ĕgitimi ve Araştırmaları Dergisi, 6(2), 1-17.

Çetinkaya, G., \& Bayat, N. (Yayım sürecinde.). Özetlemeye yönelik özyeterlik algısı ölçeğinin geliștirilmesi: Güvenirlik ve geçerlik çalışması.

Çıkrıkçı, S. S. (2004). İlköğretim öğrencilerinde özetleme becerisinin gelişimi. (Yayınlanmamış doktora tezi). Ankara Üniversitesi Sosyal Bilimler Enstitüsü, Ankara.

Çıkrıkçı, S. S. (2008). İlköğretim öğrencilerinde özetleme becerilerinin gelişimi. Dil Dergisi, 141, 19-35.

Delaney, Y. A. (2008). Investigating the reading-to-write construct. Journal of English for Academic Purposes, 7(1), 140-150.

Demir, T. (2013). İlköğretim öğrencilerinin yaratıcı yazma becerileri ile yazma özyeterlik algısı ilişkisi üzerinde bir çalışma. Uluslararası Türkçe Edebiyat Kültür Dergisi, 2(1), 84-114.

Deneme, S. (2009). İngilizce öğretmen adaylarının özetleme stratejilerini kullanım tercihleri. Journal of Language And Linguistic Studies, 5(2), 85-91.

Eagly, A. \& Chaiken, S. (1993). The psychology of attitudes. For Worth, TX: Harcourt Brace Jovanovich.

Erdem, C. (2012). Türk dili ve edebiyatı öğretmen adaylarının özetleme stratejilerini kullanım tercihleri ve metin dil bilimsel bir özetleme çalıșması. Dil ve Edebiyat Eğitimi Dergisi, 1(3), 36-52.

Eroğlu, B. (2019). Ortaokul öğrencilerinin özetleme tutumlarının bazı değişkenler açısından incelenmesi. (Yayımlanmamış Yüksek Lisans Tezi). Pamukkale Üniversitesi, Denizli. 
Eyüp, B., Stebler, M. Z. ve Uzuner Yurt, S. (2012). Türkçe öğretmeni adaylarının özetleme stratejilerini kullanmadaki eğilimleri. Dil ve Edebiyat Ĕgitimi Dergisi, 1(1), 22-30.

Fenning, B. E., \& May, L. N. (2013). "Where there is a will, there is an A": Examining the roles of selfefficacy and self-concept in college studenst' current aducational attainment and career planing. Social Psychology of Education, 16(4), 635-350.

Fidan, D., \& Gerçek, Ş. (2017). 2017 Türkçe Öğretim Programında ve ortaokul Türkçe 5. sınıf ders kitabında özetleme becerisi. O. N. Akfırat, D. F. Staub ve G. Yavaş (Ed.), Current debates in education içinde (s. 293-310). Londra: IJOPEC Publication.

Goodrich, A. H. (2001). The effects of instructional rubrics on learning to write. Current Issues in Education, $4(4), 1-28$.

Görgen, İ., \& Altıntaş, S. (2015). Analyzing pre-service teachers' skil-level on summarizing informative texts. Procedia-social and behavioral sciences, 174(12), 3005-3010.

Hampton, N. Z., \& Mason, E. (2003). Learning disabilities, gender, sources of efficacy, self- efficacy beliefs and academic achievement in high school students. Journal of School Psychology, 41(2), 101-112.

Hidi, S., \& Anderson, V. (1986). Producing written summaries: Task demands, cognitive operations, and implications for instruction. Review of Educational Research, 56 (4), 473-493.

Honicke, T., \& Broadbent, J. (2016). The influence of academic self-efficacy on academic performance: A systematic review. Educational Research Review, 17, 63-84. https://doi.org/10.1016/i.edurev.2015.11.002

İnnalı, H. Ö., \& Aydın, İ.S. (2014). İlköğretim sekiniznci sınıf öğrencilerinin okur öz yeterliklerinin çeşitli değişkenlere göre incelenmesi. International Periodical For The Languages, 9(9), 651-682.

Karatay, H., \& Okur, S. (2012). Öğretmen adaylarının öyküleyici ve bilgilendirici metinleri özetleme becerileri. The Journal Of Academic Social Science Studies, 5(7), 399-420.

Karatay, H., Güngör, H., Bolat, K. K., \& Okur, S. (2013). 6, 7 ve 8. sınıf öğrencilerinin özetleme becerileri. içinde C. Demir ve H. Parlakyıldız. (Eds.). Prof. Dr. Abdurrahman Güzel'e armağan (ss. 277-298). Ankara: Akçă̆ Yayınları.

Kintsch, W., \& van Dijk, T.A. (1978). Toward a model of text comprehension and production. Psychological Rewiew, 85(5), 363-394.

Konuk, S., Ören, Z., Benzer, A., \& Sefer, A. (2016). A Study on Creating Writing Strategy and Evaluation Tool for Book Summary. Educational Research Review, 11, 2021-2033.

McKenna, M., Kear, D., \& Ellsworth, R. (1995). Children's attitudes toward reading: A national survey. Reading Research Quarterly, 30(4), 934-956.

Pakzadian, M., \& Rasekh, A. E. (2012). The effects of using summarization strategies on Iranian EFL learners' reading. English Linguistics Research, 1(1), 118- 125.

Peura, P., Aro, T., Viholainen, H., Raikkönen, E., Usher, E. L., Soryo, R., \& Aro, M. (2019). Reading selfefficacy and reading fluency development among primary school children: Does specificity of selfefficacy matter? Learning and Individual Differences, 73, 67-68.

Stevens, E. A., Park, S., \& Vaughn, S. (2019). A review of summarizing and main idea interventions for struggling readers in grades 3 through 12: 1978-2016. Remedial and Special Education, 40(3), 131149. https://doi.org/10.1177/0741932517749940

Sulak, S. E., \& Arslan, Ş. (2017). İlkokul 4. sınıf öğrencilerinin özetleme stratejisini kullanma düzeyinin incelenmesi. Sınırsız Eğitim ve Araştırma Dergisi, 2(1), 63-77.

Susar Kırmızı F., \& Akkaya, N. (2009). University students for using the summarizing strategies. Procedia Social and Behavirol Sciences, 1, 2496-2499.

Susar Kırmızı, F., \& Akkaya, N. (2011). İlköğretimde özetleme stratejilerinin kullanımına ilişkin nitel bir araştırma. Hacettepe Üniversitesi Eğitim Fakültesi Dergisi, 41, 267-277.

Usher, E. L., \& Pajares, F. (2006). Sources of academic and self- regulatory efficacy beliefs of entering middle school students. Contemporary Educational Psychology, 31(2), 125-141.

Ülper, H., \& Okuyan, F. (2010). Quality of written summary texts: an analysis in the context of gender and school variables. Procedia Social and Behavioral Sciences, 2, 1057-1063.

Ülper, H. ve Şirin, A.N., (2019). Okuma anlama düzeyleriyle özyeterlik algısı arasındaki ilişki bağlamında ortaokul öğrencilerinin görünümleri. Pamukkale Üniversitesi Eğitim Fakültesi Dergisi, 48, 1-14.

Wenden, A. (1991). Learner strategies for learner autonomy. Prentice Hall.

Hatice Kübra Bahçıvan, Gökhan Çetinkaya

Ortaokul öğrencilerinin özetleme başarıları ile özetlemeye yönelik tutumları ve özyeterlik algıları arasındaki ilişki 
Yamaç, A., \& Öztürk, E. (2018). Türkiye'deki ilkokul öğretmenlerinin yazma öğretimi uygulamaları ve algılarının değerlendirilmesi: Bir karma yöntem araştırması. Hacettepe Üniversitesi Eğitim Fakültesi Dergisi, 33(4), 846-867.

Zenci, Ç. S. (2020). Öğretmen adaylarının metin özetleme stratejilerini kullanım tercihleri. Dil ve Edebiyat Araştırmaları, 21, 341-359. https://doi.org/10.30767/diledeara.662103

Zimmerman, B. J., \& Bandura, A. (1994). Impact of self-regulatory processes on writing course attainment. American Educational Research Journal, 31, 845-862. https://doi.org/10.3102/00028312031004845

Zumbrunn, S., Broda, M., Varier, D., \& Conklin, S. (2019). Examining the multidimensional role of selfefficacy for writing on student writing self-regulation and grades in elementary and high school. British Journal of Educational Psychology. 2019, 1-24. https://doi.org/10.1111/bjep.12315 


\section{EXTENDED ABSTRACT}

\section{Introduction}

Summarizing is a metacognitive learning strategy that is used to improve reading comprehension skills and to keep the learned information in long-term memory. Creating summary text is often assigned to students as a task by teachers in classroom settings. However, this task is about the preparation of a story or an informative text or a summary text of a novel that is read in general. It can be said that this task assigned to students by teachers may negatively affect students' attitudes towards the act of summarizing. Because the results of the relevant studies show that students' summary text writing skills are weak at all grade levels (Çıkrıkçı, 2004; Susar Kırmızı \& Akkaya, 2011; Karatay, Güngör, Bolat, \& Okur, 2013).

Summarizing skills are an act that should be gained systematically and in a planned way. In order for students to acquire this skill, it is a prerequisite for them to learn strategies that they can use in the process of summarizing reading and draft summary text creation and to develop skills in applying these strategies (Çetinkaya, Şentürk, \& Dikici, 2020). From the results of the studies on the students' level of using summarizing strategies, it can be said that students from all grade levels exhibited an inadequate view in using summarizing strategies with orientation (Deneme, 2009; Susar Kırmızı \& Akkaya, 2011; Eyüp, Stebler, \& Uzuner Yurt, (2012). Studies in the literature focus on the relationship between students' attitudes towards reading and writing or their reading and writing self-efficacy and their achievements in this field. The lack of a study dealing with the relationship between summarizing success and the attitude towards summarizing and self-efficacy draws attention as an important deficiency. The importance of this study becomes evident in that it is the first study to present a view regarding the relationship between the success of summarizing and the perception of self-efficacy and the possible contribution to be made on the subject.

The main purpose of the study is to explore middle school students' perceptions of summarizing success and their attitudes towards summarizing and self-efficacy perceptions and the relationship between them. In line with the main purpose of the study, answers to the following questions were sought:

1. What are the students' achievements in summarizing?

2. Do students' summarizing achievements differ according to grade level?

3. Do students' summarizing achievements differ by gender?

4. What are the students' attitudes towards summarizing?

5. Do students' attitudes towards summarizing differ according to grade level?

6. Do students' attitudes towards summarizing differ according to gender?

7. What are the students' perceptions of self-efficacy for summarizing?

8. Do students' self-efficacy perceptions for summarizing differ by grade level?

9. Do students' self-efficacy perceptions for summarizing differ by gender?

10. Is there a significant relationship between students' summarizing achievements and their attitude towards summarizing and their self-efficacy perception scores for summarizing?

\section{Method}

In this study, which aims to explore the relationship between summarizing achievements, attitude towards summarizing and the perception of summarizing self-efficacy, the relational screening model, one of the general screening models, was used. The participants of the study consisted of 108 secondary school students who were studying in a public school in Nizip district of Gaziantep province in the 2019-2020 academic year. In the study, "Summarizing SelfEfficacy Scale", "Attitude Towards Summarization Scale" and "Story Summary Assessment Rubric" were used as data collection tools. The data were analyzed using SPSS 22.0 statistical package programs. In the analysis of the data, the significance level (p) was accepted as 0.05 . Descriptive statistics, arithmetic mean and standard deviation were used to determine the

Hatice Kübra Bahçıvan, Gökhan Çetinkaya

Ortaokul öğrencilerinin özetleme başarıları ile özetlemeye yönelik tutumları ve özyeterlik algıları arasındaki ilişki 
summary achievement, attitude towards summarizing and self-efficacy perception for summarizing of secondary school students. In order to determine whether there is a significant difference between secondary school students' summarizing achievements according to their gender, their attitudes towards summarizing and their self-efficacy perceptions of summarizing, the normality assumption was first tested. Due to the normal distribution of the scores, whether the difference between the scores is significant according to gender was tested with the Independent Samples t-test, one of the parametric methods. As the number of students in the fifth grade is less than 30, the Kruskal Wallis test, which is one of the non-parametric methods, was tested whether there is a significant difference between the summarizing achievements, attitudes towards summarizing and summarizing self-efficacy perceptions of secondary school students according to their grade levels. "Is there a significant relationship between the summarizing achievements of secondary school students and their attitudes towards summarizing and their self-efficacy perceptions of summarizing?" Pearson Product Moments correlation coefficient was used to find an answer to the question.

\section{Result and Discussion}

According to the results obtained, students' ability to summarize is medium and their selfefficacy perceptions are sufficient. It was observed that the students believed in the importance of summarizing, liked summarizing and had a high level of positive attitude towards summarizing. It was determined that students' summarizing success, their attitudes towards summarizing and their self-efficacy perceptions did not differ significantly according to gender and grade level. Finally, it was determined that there is a moderately significant positive correlation between the students' summarizing achievements, their self-efficacy perceptions and their attitudes towards summarizing.

The results of this research revealed that secondary school students' positive attitudes towards summarizing and their high self-efficacy perceptions are an important variable in terms of their success in summarizing. In addition, it is a striking result that as the class level increases, their attitudes and self-efficacy perceptions decrease. The biggest mistake in the teaching environment is that students are often given homework to summarize a novel they read or a text in a textbook, based on the idea that they have summarizing skills. Giving students' summarizing tasks that they cannot cope with may lead to a negative attitude towards summarizing and also reduce their self-efficacy perceptions of summarizing. Therefore, summarizing tasks that students cannot tackle should be avoided. Instead, a gradual skill development should be adopted in line with a sequential and spiral curriculum in line with language developments. 